\title{
ZWIASTOWANIE MARII W POLSKIEJ SZTUCE ŚREDNIOWIECZNEJ
}

Zwiastowanie Marii, opisane w Ewangelii według św. Łukasza i przez apokryfy Nowego Testamentu, było przedmiotem rozważań wielu teologów, których myśli przejęły sztuki plastyczne. Niektóre motywy, powtarzające się w scenach zwiastowania Marii, przedstawia niniejszy artykuł ${ }^{1}$. Jego celem jest między innymi ukazanie i interpretacja motywów występujących w sztuce polskiej oraz wyszczególnienie związków ikonograficznych istniejących między obrazami polskimi a wcześniejszymi od nich europejskimi scenami, które w dalszej perspektywie miały wpływ na powstanie typów ikonograficznych w zwiastowaniach polskich.

\section{OBLUBIENICA BOGA}

Na niezachowanym malowidle ściennym $\mathrm{z}$ lat $1500-1510$, na ścianie jednego z przęseł krużganków kościoła OO. Dominikanów w Krakowie, znanym tylko z rysunku (il. 1) ${ }^{2}$, wewnątrz mieszkania, w którym ukazani są Maria i anioł, w głębi za Marią stoi baldachimowe łoże. Od medalionu Boga Ojca, który umieszczony jest nad wejściem, w stronę Marii zlatuje Duch Swięty ${ }^{3}$.

Motyw łoża we wnętrzu mieszkalnym, w którym ma miejsce zwiastowanie, zauważa we włoskim malarstwie okresu trecenta Herman Beenken. Swymi początkami może on sięgać obrazu na fresku młodego Giotta, w prawym ramieniu transeptu dolnego kościoła Św. Franciszka z Asyżu. Niskie mieszkanie bez mebli, jedynie $\mathrm{z}$ łóżkiem $\mathrm{w}$ drugim pomieszczeniu, prezentuje obraz na predelli, namalowany przez Barnabę z Modeny. Dwoma innymi przykładami

${ }^{1}$ Artykul jest częścią czwartego rozdziału pracy magisterskiej napisanej pod kierunkiem prof. dr hab. J. Gadomskiego, w Zakładzie Historii Sztuki Sredniowiecznej Uniwersytetu Jagiellońskiego, w roku akademickim 1989/90.

2 Kornecki M., Małkiewiczówna H., Małopolska, [w:] Gotyckie malarstwo ścienne $w$ Polsce, Poznań 1984, s. 60, 68, 201.

${ }^{3} \mathrm{~K}$ a rł ow ska-K a m zow a A., Kodeksy importowane, [w:] Malarstwo gotyckie na Pomorzu Wschodnim, Warszawa-Poznań 1990, s. 189 (il. 104). 
są: fresk Barna da Siena w kolegiacie w S. Gimignano i na ołtarzu Giovenniego da Milano w Muzeum Palazzo Venezia w Rzymie ${ }^{4}$.

Ten rodzaj zwiastowania spotykany jest w pierwszych trzech dekadach XV wieku w malarstwie niemieckim i niderlandzkim, które stało się jednym ze źródeł idei zapóżyczonych do ukształtowania wnętrza mieszkalnego (mieszczańskiego) w scenie zwiastowania Marii w malarstwie flamandzkim. Na białoczarnej miniaturze z lat 1410 - 1420, w kodeksie (środkowo-niderlandzkim dziele) z Arnstein an der Lahn, a teraz w Staatsarchiv w Wiesbaden, Maria siedzi na łożu pod baldachimem $\mathrm{z}$ wiszącymi na jego rogach ozdobami (pendants), które potem będą się pojawiać w o wiele późniejszych przykładach flamandzkich. Podobną koncepcję, ale bardziej rozbudowaną prezentuje zwiastowanie na rewersach ołtarza z Brenken, z lat 1420 - 1430, przypisywanego kolońskiemu mistrzowi Hermanowi Wynrichsowi w Staatliche Museen Preussischer Kulturbesitz w Berlinie. W tylnej części pokoju, za zasuwaną kotarą, stoi łoże. Sufit jest pokryty belkami, a szyby ułożone są w oknach diamentowo ${ }^{5}$. Koncepcja ta przyjęta została przez włoskich propagatorów stylu międzynarodowego. Przykłady stanowią: fresk z lat $1424-1431$, Pisanella, na łuku prezbiterium w S. Fermo w Weronie; malowidło wykonane przez uczniów Fra Angelico w S. Martino a Mensola; Zwiastowanie Masolina w kolekcji Goldmana w Nowym Jorku, w którym łoże jest też dyskretnie zaznaczone ${ }^{6}$.

Znaczenie łoża we wnętrzu, w którym anioł zwiastuje Marii wolę Boga, wyjaśnia w pełni Roger van der Weyden w obrazie zwiastowania, z lat 1434 1435, w Muzeum Luwru w Paryżu, skomponowanym według wzoru komnaty ślubnej Małżeństwa Arnolfinich Jana van Eycka ${ }^{7}$. U wezgłowia łoża bowiem artysta umieścił wiszący medalion z „podobizną” Chrystusa. Ślubny pokój z łożem w tym kontekście staje się thalamus Virginis, który wyjaśnia tradycja patrystyczna kościoła zachodniego w interpretacji Pieśni nad Pieśniami, tłumacząca, że Maria była predestynowana do tego, by stać się oblubienicą drugiej osoby boskiej - Syna Bożego. Wstępując do świątyni, zawarła mistyczne zaślubiny z Oblubieńcem przez złożenie ślubu czystości (votum virginitatis), który był znakiem mającego nastąpić wkrótce Wcielenia ${ }^{8}$ (św. Augustyn mówi, że Maria nie powiedziałaby aniołowi: „Jakże się to stanie, skoro męża nie znam”, gdyby wcześniej nie złożyła ślubu dziewictwa ${ }^{9}$ ). Koncepcję Wcielenia, jako za-

${ }^{4}$ Beenken H., The Annunciation of Petrus Christus in the Metropolitan Museum and the Problem of Hubert van Eyck, „The Art Bulletin” $19: 1937$ s. 224 (il. 2,4 - 5); F a is on S. L. jr., Barna and Bartolo di Fredi, „The Art Bulletin” 14 : 1932 nr 4 s. 285 nn. (il. 24).

${ }^{5}$ Robb D.M., The Iconography of the Annunciation in the Fourteenth and Fifteenth Centuries, „The Art Bulletin” $18: 1936$ s. 503.

6 Tamże, s. 519; Pa n of sk y E., Early Netherlandish Painting. Its Origins and Charakter, Cambridge, Mass. 1953, s. 129 (przypis 129, 9), 254 (przypis 5).

${ }^{7}$ Pan of s k y E., Early Netherlandish Painting..., s. 254.

8 Dobrze ni ecki T., Prezentacja Marii w świątyni wedtüg Wita Stwosza w krakowskim ottarzu Mariackim, „Biuletyn Historii Sztuki” $36: 1974$ s. 1 s. 6.

${ }_{9} \mathrm{G}$ ös s m a n M.F., Die Verkündligung an Maria in dogmatischen Verständnis des Mittelalters, München 1957, s. 16 - 17; D obrzenie ck i T., Prezentacja Marii w'śątyni..., s. 7. 
ślubin, wywodzącą się od Wyznań św. Augustyna ${ }^{10}$, rozwijali Rupert z Deutz (1070 - 1129), który w In cantica canticorum de incarnatione Domini comentarii cały ten utwór interpretuje jako rozmowę Oblubieńca-Chrystusa z Oblubienicą-Marią ${ }^{11}$, i Honoriusz z Autun $(1090$ - 1156) w swoim Expositio in cantica canticorum, uważający osoby w Pieśni nad pieśniami jako małżonka i małżonkę, Chrystusa i Marię. Honoriusz spośród trzech rodzajów zaślubin o pierwszych z nich mówi: Primae nuptiae erant, quando Rex coeli Filio suo Christo humanam naturam copulavit, ubi thalamus Virginis, uterus fixit, de quo „ut sponsus de thalamo processit" (Ps. 37,6). Ad has nuptias omnes ante legem patriarchas, omnes sub lege prophetas invitavit ${ }^{12}$. Iwo z Chartres, wyjaśniając Ps. 19(18),6, w którym słońce porównywane jest do narzeczonego opuszczającego sypialnię, utrzymuje, że jest tu mowa o zwiastowaniu, przy czym Najświętszą Marię Pannę określa jako sypialnię Chrystusa - Słońca ${ }^{13}$.

Ten motyw z lożem, ale bez medalionu, zostal jeszcze raz powtórzony przez van der Weydena w zwiastowaniu na skrzydle ołtarza z lat około 1458 1459, z kościoła Sw. Kolumbana w Kolonii ${ }^{14}$ i Petrusa Christusa na kwaterze lewego skrzydla tryptyku z 1452 r. w Staatliche Museen Preussischer Kulturbesitz w Berlinie ${ }^{15}$. Zlatujący po promieniu Duch Święty w Zwiastowaniu Rogera nawiązuje do koncepcji Ruperta z Deutz, że Maria jest nie tylko oblubienicą Syna, lecz także Ojca. Jej osoba w akcie Wcielenia była ukochaną przez nich obu świątynią, zamieszkiwaną przez Ducha Świętego. Dla Boga Ojca była „prawdziwą małżonką" i „wieczną przyjaciółką”, dla Chrystusa małżonką i matką, dla Ducha, z którego poczęła Syna, była „świątynią właściwą miłości"16. Idea zaślubin Marii przez Boga Ojca w krakowskim malowidle wyrażona została przez obecność jego popiersia w medalionie i Ducha Świętego zsyłanego na Marię.

Innym znakiem zaślubin jest korona włożona na skronie Marii w scenie zwiastowania. W kodeksie lubińskim, z legendą o św. Jadwidze ${ }^{17}$ (il. 2), czoła ukoronowanej Marii dotyka Duch Święty, a nad klęczącym przed nią aniołem,

${ }^{10}$ A u gu st y n, Wyznania IV 12, Warszawa 1955, s. 115.

${ }^{11}$ Rupert z Deutz $(1070$ - 1129), In cantica canticorum de incarnatione Domini comentarii, PL 168 szp. 837 - 962; zob. D o b rze n i e cki T., Prezentacja Marii wświatyni ..., s. 6 (przypis 21).

${ }_{12}$ Honorius Augustodunensis, Expositio in Cantica Canticorum, PL 172 szp. 349; G r a czy k H., Zwiastowanie, [w:] Maria Matka Chrystusa. Ikonografia nowożytnej sztuki kościelnej w Polsce, pod red. ks. J. St. Pasierba, t. 1, Warszawa 1987, s. 130 - 131

${ }^{13}$ Schill e r G., Ikonographie der christlichen Kunst, Band 1, Gütersloh 1981, s. 61.

${ }^{14} \mathrm{P}$ a n of s k E., Early Netherlandish Painting..., s. 286 - 287 (il. 354); R ob b D. M., The Iconography, s. $508-512$.

${ }_{15}$ Pa n of s k y E., Early Netherlandish Painting, s. 311 il. 409.

16 Ohly F., Hohelied-Studien. Grundzüge einer Geschichte der Hoheliedauslegung des Abèndlandes bis um 1200, Wiesbaden 1958, s. 127; G ra czyk H., jw., s. 130.

17 Karłowska-Kamzowa A., Malarstwo ślaskie 1250 - 1450, Wrocław-WarszawaKraków-Gdańsk 1979, s. 110 - 111; taż, Malarstwo gotyckie Europy środkowowschodniej. Zagadnienie odrębności regionu, Warszawa-Poznań 1982, s. 26-27 (il. 35). Kodeks lubiński, z legendą o św. Jadwidze, z 1353 r., znajduje się obecnie w John Paul Getty Museum w Malibu. Tę informację zawdzięczam Pani mgr Annie Palińskiej, za co pragnę jej podziękować. 
po lewej stronie sceny Bóg Ojciec, wychylający się z mandorli, wysyła w stronę Marii, trzymane w swoich dłoniach, nagie Dzieciątko. W Graduale otbińskim (IF 423) do czoła ukoronowanej Marii zbliża się Duch Święty, który spada z chmury po promieniach będących znakiem Bożego działania ${ }^{18}$ (il. 3). Na witrażu z fary chełmińskiej ${ }^{19}$, oprócz Ducha Świętego, kierującego się ku ukoronowanej Marii, obok niej stoi lichtarz z palącą się na nim świecą. Polichromia w kościele p.w. św. Kosmy i Damiana w Okoninie (il. 4) przedstawia Marię w koronie, siedzącą na ławie ${ }^{20}$. Maria ma włożoną na głowę koronę na witrażu w kościele Mariackim w Krakowie ${ }^{21}$ (il. 5), a także na miniaturze w Concordantiae Bibliorum (il. 6), namalowanej przez Mateusza z Oleśnicy (IF 88) ${ }^{22}$, na której Bóg Ojciec posyła do Marii Ducha Świętego i nagie Dzieciątko z krzyżem na ramieniu. Najciekawiej przedstawiona jest Maria na obrazie znajdującym się w głównym ołtarzu kościoła parafialnego w Zagórzu k. Sanoka ${ }^{23}$ (il. 7). Maria $\mathrm{z}$ rozłożonymi rękami, jak orantka, zwrócona jest w stronę anioła, a na Jej głowę dwaj aniołowie wkładają coronam clausam. Od popiersia Boga Ojca, w Jej stronę, spływa po promieniach nagie Dzieciątko. Koronę posiada Maria w zwiastowaniu na płaskorzeźbie w katedrze w Bambergu (1230 1240). G. Schiller mówi, że przedstawiona jest Ona tutaj nie jako księżniczka, ale jako królewska narzeczona, stojąca przed posłem swego Pana ${ }^{24}$.

Korona, która dla Marii jest znakiem egzystencji jako oblubienicy Boga ${ }^{25}$, ma swoje reperkusje w życiu zakonnym. W specjalnym obrzędzie liturgicznym biskup błogosławi, konsekruje i zaślubia zakonnicę z Chrystusem. W porządku ontologicznym poświęcona Bogu dziewica jest oblubienicą Chrystusa, ponieważ uczestniczy w oblubieńczym związku Marii ż Chrystusem (stąd od zarania średniowiecznego życia monastycznego uznawano też Marię za pierwszą niewiastę, która złożyła profesję zakonną). Według rzymskiego zwyczaju biskup dawał więc dziewicom pierścień (annulus pronubus, sponsalicium), a na

18 Wrocław, Biblioteka Uniwersytecka, sygn. IF 423 f. 3r; D o b r ow ols ki T., Sztuka na Slasku, Katowice-Wrocław 1948, s. 185; K a rł ow s k a - K a m z o w a A., Malarstwo ślaskie 1250 1450 , s. 25 (il. 27).

19 B u c z k ow s k i K., Dawne szkła artystyczne w Polsce, Kraków 1958, s. 31 - 33; Ka rł ow s k a-Ka m zow a A., Malarstwo gotyckie Europy środkowowschodniej..., s. 36.

20 D o m a s l ow s ki J., Pomorze Wschodnie, [w:] Gotyckie malarstwo ścienne w Polsce..., s. 127, 131, 234; Katalog zabytków sztuki w Polsce, t. 11 z. 7 s. 50 (il. 103).

${ }^{21}$ B rzu s ki H., Witraże średniowieczne w kościele N.P. Maryi w Krakowie [w:] Bibljoteka historii sztuki, t. 1, Kraków 1926, s. 16, 34; B u czk ow ski K., jw., s. 16-19. Ch ruszczyńs k a J., Średniowieczne witraże małopolskie, [w:] Polskie szkło do połowy XIX wieku, Wrocław-Warszawa-Kraków-Gdańsk-Eódź 1989, s. 162 (il. 142).

22 Wrocław, Biblioteka Uniwersytecka, sygn. IF 88 f. lr.; K1 os s E., Schlesische Buchmalerei des Mittelalters, Berlin 1942, s. 190 (il. 235); Dobrowols ki T., Sztuka na Ślasku, KatowiceWrocław 1948 , s. 191. 171.

${ }^{23} \mathrm{G}$ a d o m s ki J., Gotyckie malarstwo tablicowe Małopolski 1460 - 1500, Warszawa 1988, s.

24 Schiller G., jw., s. 50 przypis 30 (il. 89).

25 Hall E., Uhr H., Aureola and Fructus: Distinctions of Beatitude in Scholastic Thought and the Meaning of Some Crowns in Early Flemish Painting, ,The Art Bulletin” 60: 1978 s. 249 270; B rand Philip L., The Ghent Altarpiece nad the Art of Jan van Eyck, Princeton (New Jersey) 1971 , s. $78-97$. 
głowę wkładał coronam virginalem. Klasztor benedyktynek Nonnberg w Salzburgu przechował dawny ryt profesji, szczegółowo opisany w $1530 \mathrm{r}$. Na uwagę zasługuje końcowy obrzęd: opatka wkłada na głowę nowej profeski ozdobny wieniec, na palec pierścień i wręcza oblubieńca, którym był ,pięknie ozdobiony krucyfiks". W tym samym klasztorze zachowały się figurki Dzieciątka Jezus, które zakonnice otrzymały od swoich krewnych na uroczystość profesji, przechowywały je w swoich celach, posługiwały się nimi przy odnowieniu ślubów, przeważnie w dzień święta ofiarowania Marii w świątyni lub na święto patrona zakonu ${ }^{26}$.

Sztuka późnego średniowiecza wprowadziła do sceny Zwiastowania motyw Logosu-dziecka, wysyłanego przez $\mathrm{Ojca}^{27}$, podobnie jak to jest na miniaturze kodeksu z legendą św. Jadwigi, na której Bóg Ojciec wysyła Gabriela do Marii i Syna - Słowo niewcielone - w postaci małego dziecka, podczas zwiastowania $^{28}$. W scenie zwiastowania, w kontekście korony na głowie Marii, jego pojawienie się akcentuje moment zaślubin, jak to w szczególny sposób podkreślone jest w zwiastowaniu w Zagórzu, gdzie akt koronacji jest zsynchronizowany $\mathrm{z}$ ruchem nagiego Dzieciątka, postępującym od popiersia Boga Ojca w stronę Marii.

Zaślubiny na witrażu chełmińskim, oprócz Ducha Świętego, podkreśla lichtarz z palącą się świecą. Panofsky, tłumacząc znaczenie lichtarza w Zwiastowaniu Mistrza z Flémalle (Roberta Campin) z kolekcji Merode, mówi, że lichtarz z osadzoną na nim świecą symbolizującą Chrystusa jako dziecko, które matka czuje w swoim łonie, był powszechnie symbolem Matki Najświętszej. Speculum humanae salvationis podaje tekst odnoszący się do Marii i stwierdzający, że „ipsa enim candelabrum et ipsa est lucerna [...] Christus, Mariae filius, est Candela accensa"29. Margaret Freeman, pisząc o Zwiastowaniu Mistrza z Flémalle, z kolekcji Merode mówi, że Durandus i inni tłumaczą wosk świecy jako ten, „który został wyprodukowany przez dziewicze pszczoły, reprezentuje człowieczeństwo, lub ciało Chrystusa [...], knot znajdujący się w wosku przedstawia jego duszę". Swiatłọ świecy ukazuje jego bóstwo ${ }^{30}$.

${ }^{26}$ Dobrzeniecki T., Prezentacja Marii wświatyni..., s. $8-9$.

27 R obb D.M., s. 523- 526; Guld a n E., „Verbum caro factum est”. Die Darstellung der Inkarnation Christi im Verkündigungsbild, ,Römische Quartalschrift für christliche Altertumskunde und Kirchengeschichte" 63: $1968 \mathrm{~s}$. 145 - 169; D obrzeniecki T., U źródet przedstawień: Tron Łaski i Pietas Domini, „Rocznik Muzeum Narodowego w Warszawie” 15 : 1970 s. 232 (il. 5); tenże, Prezentacja Marii w światyni..., s. 11.

28 D obrzenie cki T., Prezentacja Marii wświatyni, s. 11 (przypis 52). Ten rodzaj rozbudowanego zwiastowania przyjął się pod wpływem św. Bonawentury; por. B e is s e l St., Die Bildliche Darstellung der Verkündigung Mariä, "Zeitschrift für christliche Kunst” 4: 1891 s. 192; R ob b D.M., jw., s. 524.

${ }_{29} \mathrm{P}$ a n of s k y E., Early Netherlandish Painting, s. 143 (przypis 2); Robb D., jw., s. 504.

${ }^{30} \mathrm{Fr}$ e e m a M., The iconography of the Merode Altarpiece, "The Metropolitan Museum of Art Bulletin" $16: 1957$ z. 4 s. 134 . 
SUB LEGE, SUB GRATIA. CHRYSTUS-ADAM, MARIA-EWA

Na kilku przedstawieniach znakiem określającym treść sceny jest drzewo, które wyrasta z ziemi i usytuowane jest bliżej Marii lub służy jako noga pulpitu z leżącą na nim książką. W przypadku pateny kaliskiej (il. 8) P. Skubiszewski pisze:

Przedstawienie Drzewa Życia i wprowadzenie motywu Adama podnoszącego się z grobu, a przy tym wskazującego na Chrystusa dowodzi, że zamiarem autora programu było rozszerzenie prostej redakcji trójosobowej grupy Ukrzyżowania o ilustrację antytezy Adam-Chrystus. Pierwszy św. Paweł przeciwstawił praojca wszystkich ludzi i sprawcę ich upadku Zbawicielowi (Rz. 5,12 20; 1 Kor. 12,21 - 22 i 45). [...] Z myślami tymi ściśle są związane przedstawienia na brzegu pateny. Zwiastowanie stoi na początku Dzieła Odkupienia. Jest obrazem Wcielenia i przypomina o tym, że Bóg, by zbawić człowieka, przyjął jego naturę. Jednocześnie ukazuje posłuszeństwo Marii jako antytezę nieposłuszeństwa pierwszego czlowieka ${ }^{31}$.

Wydaje się, że w scenie zwiastowania Maria przedstawiona jest u wrót raju, ponieważ zza wieży stojącej po prawej stronie Marii wynurza się korona drzewa. Aluzja do antytezy Maria, jako druga Ewa, nabiera więc znaczenia, jakie wyraża miniatura z około 1280 roku (Madryt, Real Biblioteca de El Escorial, Cod. T. I. 1: Pieśni Maryjne Alfonsa Mądrego, miniatury do 60. pieśni, fol. $\left.88^{\mathrm{v}}\right)^{32}$, na której około sto lat później od powstania naszej pateny ukazane jest wygnanie $\mathrm{z}$ raju pierwszych rodziców i wprowadzenie zbawionych bramą rajską przez Marię, zamknięcie wrót nieba przez Adama i Ewę i otwarcie ich przez Marię w chwili Zwiastowania. A więc przez upadek Ewa zamknęła bramę raju i nieba, a Maria przez Ave anioła i swoje fiat te drzwi otwarła.

Tę samą myśl wyrażają przy końcu średniowiecza otwarte drzwi komnaty, w której anioł objawia się Marii w zwiastowaniu na rewersach ołtarza z lat między 1473 a 1478, z kaplicy bractwa kapłańskiego w kościele Mariackim w Gdańsku ${ }^{33}$; na rewersie skrzydła ołtarzowego z 1480 r., w kościele Sw. Jana w Toruniu (il. 9) ${ }^{34}$; na pentaptyku z lat pomiędzy 1485 a 1490 , ufundowanego przez Jana Ferbera dla kościoła Mariackiego w Gdańsku (il. 10) $)^{35}$ i na miniatu-

31 S k ubiszews k i P., Patena kaliska, „Rocznik Historii Sztuki” 3 : 1962 s. 205 - 206; por. tenże, Programy obrazowe kielichów i paten romańskich, tamże 13:1981 29, 30.

32 Guld an E., Eva und Maria. Eine Antithese als Bildmotiv, Graz-Köln 1966, s. 58 - 59, 178 (il. 39).

${ }_{33}$ Dobrze niecki T., Malarstwo tablicowe. Katalog zbiorów, Warszawa 1972, s. 135-140 (il. 41 C202); L a bu d a A., Malarstwo tablicowe $w$ Gdañsku w drugiej potowie XV w., Warszawa 1979 , s. 53 - 58 (il. 2).

34 Wa li ck i M., Polska sztuka gotycka. Katalog wystawy zorganizowanejprzez Towarzystwo Opieki nad Zabytkami Przesztości w Warszawie (kwiecień - maj 1935 roku), Warszawa 1935, s. 46; La bu da A., Malarstwo tablicowe..., s. 83 (il. 58); Łoś W., Program ikonograficzny kwatery Świętej Trójcy poliptyku toruńskiego, [w:] Sztuka Torunia i Ziemi Chetmińskiej 1233 - 1815, Warszawa-Poznań-Toruń 1986, s. 128.

${ }_{35}$ Dobrzeniecki T., Malarstwo tablicowe..., s. 145-147 (il. 45 B2C2); Labuda A., Malarstwo tablicowe..., s. $79-85$ (il. 54). 
rze (il. 2) modlitewnika przechowywanego w Bibliotece Uniwersyteckiej w Toruniu (rps 85 , fol. $12^{\mathrm{v}}$ ), a także na zewnętrznej stronie skrzydeł ołtarzowych z około 1500 r. w ewangelickim kościele w Krzywiźnie ${ }^{36}$.

Wcześniej, otwarte drzwi komnaty, przez które zaglądają do jej wnętrza donator (Inghelbrechts z Malins) i jego żona, ukazane są w scenie Zwiastowania Mistrza z Flémalle ze zbiorów Merode ${ }^{37}$. W otwartych drzwiach pryklęka anioł na obrazie Zwiastowania z około 1445 r. Dirka Boutsa z kolekcji Prado w Madrycie ${ }^{38}$. Przez otwarte drzwi wszedl anioł do komnaty, w której Maria siedzi na podłodze, przed baldachimowym łożem, w zwiastowaniu na kwaterze lewego skrzydła tryptyku Petrusa Christusa w berlińskich Staatliche Museen Preussischer Kulturbesitz ${ }^{39}$. W powstałym pod wpływem flamandzkiego malarstwa dziele Mistrza Górnoreńskiego z 1440 r., w kolekcji O. Reinharta w Winterthur, drzwi komnaty, usytuowane za aniołem, są lekko uchylone ${ }^{40}$. Otwarte drzwi pozostawił anioł w zwiastowaniu (które wykazuje wpływ ołtarza gandawskiego) na rewersach skrzydeł tryptyku z 1471 r. z Mosoc Mistrza GH, w Galerii Narodowej w Budapeszcie ${ }^{41}$. Przez podwójny otwór drzwiowy wszedł anioł do pomieszczenia, w zwiastowaniu na skrzydłach ołtarza z Ehningen z około 1476 roku, malarza południowoniemieckiego zwanego Mistrzem ołtarza z Ehningen w Gemäldegalerie w Stuttgarcie ${ }^{42}$.

We wspomnianym już artykule Margaret Freeman, zastanawiając się nad otwartymi drzwiami w Zwiastowaniu Mistrza z Flémalle z kolekcji Merode i cytując teksty śś. Bernarda i Tomasza a Kempis (o zamkniętych drzwiach izdebki, w której modliła się Maria i że Ona sama jest zamkniętą bramą, która w poczęciu i porodzeniu pozostała zawsze nietkniętą dziewicą) zapytuje między innymi, czy Campin nie miał na myśli symboliki zaczerpniętej od Jakuba de Voragine, że „brama rajska, która przez Ewę była zamknięta dla wszystkich ludzi, teraz jest otwarta dzięki Najświętszej Marii Pannie"43. Jest to prawdopodobne, jeżeli nad otwartymi drzwiami komnaty, do której wszedı anioł, we wspomnianym zwiastowaniu na rewersach skrzydeł ołtarza z Ehningen w Gemäldegalerie w Stuttgarcie ${ }^{44} \mathrm{w}$ tympanonie ukazana jest scena rajska, w której po obu stronach drzewa z wężem stoją Adam i Ewa podająca Adamowi zakazany owoc. Podkreśla to też Carla Gottlieb, która rozważając symbolikę ołtarza

${ }^{36}$ Braune H., Wiese E., Schlesische Malerei und Plastik des Mittelalters, [w:] Kritischer Katalog der Ausstellung in Breslau 1926, Leipzig 1929, s. 96 - 97 (il. 210).

${ }^{37}$ Ro u s s e u T. jr., The Merode Altarpiece, „The Art Bulletin” 16: 1957 z. 4 s. 125.

$38 \mathrm{P}$ a n of s k y E., Early Netherlandish Painting..., s. 314 (il. 414).

39 Tamże, s. 311 (il. 109).

${ }^{40}$ Rob́b D. M., jw., s. 514 (fig. 36).

${ }^{41}$ The Hungarian National Gallery. The Old Collections (tekst notki oprac. Gyöngyi Török), Budapest 1984, il. 39.

42 Sch ö ne W., Dieric Bouts und seine Schule, Berlin-Leipzig 1939, tabl. 41; G u ld an E., Eva und Maria..., s. 71, 186 (il. 60); W i e m a n n E., Altdeutsche malerei, Stuttgart 1989, s. 23 (il. 20).

${ }^{43}$ Freeman M., jw., s. 165.

${ }^{44} \mathrm{Guld}$ a E., Eva und Maria..., s. 71, 186 il. 60. 
Zwiastowania Mistrza z Flémalle mówi, że otwarte drzwi w obrazach przedstawiających Wcielenie lub zwiastowanie są nawiązaniem do bramy rajskiej, zamkniętej dla ludzi przez grzech pierwszych rodziców i otwartej ponownie przez ofiarę Chrystusa. Cytuje przy tym pseudo-Augustyna kazanie 120 in Natali Domini, w którym mówi: Brama nieba od dawna zamknięta przez Adama już wydata dźwięk [...] $O$, Panno wieczysta, to teraz twoja wiara albo otworzy albo zamknie niebo $o^{45}$. O ile przy zamkniętych drzwiach podkreślone jest dziewicze macierzyństwo Marii, o tyle przy otwartych drzwiach akcent jest położony na odkupienie ${ }^{46}$. Maria staje się bramą rajską prowadzącą do nieba (paradisi porta). Sw. Efrem Syryjczyk w kazaniu Ku chwale Bożej Rodzicielki Dziewicy Marii woła: Witaj, bramo niebieska i drabino dla wejścia wszystkich! Witaj, Ty otwierasz bramę do raju niebios! ${ }^{47}$ Sw. Jan Damasceński w homilia na Wniebowzięcie NMP poucza: Wtedy to nasi rodzice Adam i Ewa z radościa zawotali [...] My zamknęliśmy raj, ty otworzytaś nam drogę do drzewa życia ${ }^{48}$. W hymnie Akathistos zawarte jest pozdrowienie skierowane do Marii: Zdrowaś, bramo zbawienia 49 .

Samo drzewo, porośnięte liśćmi, pojawia się na tympanonie w bazylice p.w. św. Trójcy w Strzelnie ${ }^{50}$ i na kolumnie ornatu św. Jadwigi z Henrykowa (il. 11) ${ }^{51}$. Odnośnie do Strzelna Zygmunt Świechowski pisze, że „Maria jest drugą Ewą, która zapobiega skutkom grzechu pramatki sięgającej po zakazany owoc z drzewa wiadomości dobrego i złego - drzewa śmierci"52. Przykłady dla przedstawienia drzewa w scenie zwiastowania odnajdujemy: na fresku w kościele S. Maria w Castelseprio (VII - X w.), nä którym drzewo znajduje się obok Marii; na płaskorzeźbie z kości słoniowej z czwartej ćwierci X w., w berlińskim Staatliche Museum (nr inw. 567), na którym Maria i anioł rozmawiają, stojąc po obu stronach drzewa; na płaskorzeźbie drzwi z brązu w katedrze w Monreale (1186 r.), gdzie gałąź z drzewa zwisa $z$ dachu budowli, przed którą stoi Maria ${ }^{53}$, oraz na miniaturze romańskiego rękopisu w Dreźnie (Lan-

45 Gottlieb C., jw., s. 67.

46 Tamże, s. 67.

47 Ojcowie Kościoła greccy i syryjscy. Teksty o Matce Bożej, przełożył i poprzedził wstępem ks. W. Kan i a, Niepokalanów 1981, s. 71; por. G ot tl i e b C., A Sienese Annunciation and its Fenestra Cancellata, „Gazette des Beaux-Arts” $83: 1974$ s. 93.

48 Tamże, s. 249.

49 Tamże, s. 277.

50 Sztuka polska przedromańska i romańska do schyłku XIII wieku, red. M. W alicki, Warszawa 1971, s. 213 (il. 516); Ś w i e ch ow s ki Z., Strzelno. Rzeźba romańska, Strzelno 1987, s. 8(il. 3); tenże, Nieznane rzeźby romańskie w Strzelnie, ,Biuletyn Historii Sztuki” 49: 1987 z. 1/2 s. 165 .

51 Sztuka polska przedromańska i romańska..., s. 295 rys. 123.

52 Świechow ski Z., Strzelno..., s. 8.

53 Schille r G., jw., s. 50; Dictionnaire d'archéologie chretienne et de liturgie, publie par Le R. P. dom Fernerd Cabrol abbe Saint-Michel de Franborough (Angleterre) avec le concours d'un grand nombre de colaborateurs, t. 1 cz. 2, Paris 1907, szp. 2263 (il. 767). Drzewo na fresku w Castelseprio nie jest tak silnie zaznaczone, jak np. na płaskorzeźbie z kości słoniowej z Reichenau ( Schille r G., jw., il. 77) i nie wywołuje wspomnień pierwszego upadku. Może dlatego A. Ró ży cka-Bryzek (Malowidta ścienne w kościele Santa Maria w Castelseprio, „Rocznik Historii Sztuki" 3 : 1962) nie wspomina o nim omawiając malowidla ścienne w Castelseprio. 
desbibliothek, Cod. A 165, fol. $7^{\text {r }}$ ), na której małe drzewo wyrasta pomiędzy stojącymi profilowo, dość blisko siebie, Marią i Gabrielem ${ }^{54}$.

Wymienione sceny są odzwierciedleniem wspomnianej przez Świechowskiego antytezy Maria-Ewa. Spośród Ojców Kościoła Św. Justyn w Dialogu $z$ żydem Tryfonem podjął myśl o zbawczej roli Marii jako nowej Ewy w związku z ideą rekapitulacji i recyrkulacji. Ewa bowiem, jako dziewica nienaruszona, poczęła słowo wężowe i zrodziła nieposłuszeństwo i śmierć. Wiarę natomiast i radość poczęła Dziewica Maria, gdy Gabriel zwiastował Jej Dobrą Nowinę. Odpowiedziała: Niech mi się stanie wedtug stowa twego. Sw. Ireneusz w Adversus Haereses, mówiąc o rekapitulacji, czyli odnowy wszystkiego w Chrystusie, wspomina także o Marii, gdy „Ewa przez nieposłuszeństwo swoje stała się przyczyną śmierci dla siebie i całego rodzaju ludzkiego". O antytezie Ewa-Maria mówili także: Tertulian, Efrem, Epifaniusz, Cyryl Aleksandryjski, Ambroży ${ }^{55}$, a także Hieronim, Augustyn i Piotr Chryzolog ${ }^{56}$. W armeńskiej Księdze dziecięctwa zawarta jest myśl, że Maria to nowa Ewa, która ma odkupić winę pierwszej ${ }^{57}$.

Na malowidle ściennym w kościele parafialnym w Czchowie (il. 12) ${ }^{58}$ drzewko wyrastające $z$ ziemi i puszczające pędy stanowi nogę pulpitu, na którym leży otwarta książka przed stojącą Marią. Jerzy Gadomski mówi, że „motyw drzewka puszczającego pędy spełnia tu rolę arbor vitae, jako symbolu zmazania grzechu pierworodnego przez mającego się narodzić Zbawiciela. Puszczająca pędy gałązka jako symbol nadziei i rodzącego się życia, oznacza zapowiedź zbawienia i przełomowy moment Zwiastowania, kończący się erą sub Lege i otwierający nową erę sub Gratia"59. Podaje przy tym przykład miniatury bolońskiej z połowy XIV w., na której powiązanie motywu drzewa ze sceną zwiastowania podbudowane jest wątkiem dodatkowym - Maria obejmuje ręką pień, wokól którego obraca się wąż 60

W Antyfonarzu lubiaskim (IF 401) ${ }^{61}$ postacie Marii i anioła wpisane są w górną część wolnych pól pomiędzy pionowymi laskami inicjału M(issus).

${ }^{54}$ Dobrzeniecki T., Legenda o Secie i drzewie życia w sztuce średniowiecznej, „Rocznik Muzeum Narodowego w Warszawie" 10 : 1966 s. 178 (il. 5).

55 Flor k ow ski E., Matka Boża w nauce Ojców Kościoła, [w:] Gratia lena. Studia teologiczne o Bogurodzicy, red. B. P.r z y b y ls k i e g o OP, Poznań-Lublin-Warszawa 1965, s. 61, 64, 67 $-68,71,76$.

56 Bialic D., ks., Duchowe macierzyństwo Matki Zbawiciela, [w:] Gratia plena..., s. 258 przyp. 37; G ra czy k H., jw., s. 135; Ojcowie Kościoła łacińscy. Teksty o Matce Bożej, przelożyli ks. W. Eborowicz, ks. W. Kani a, poprzedził wstępem ks. W. K a nia, Niepokalanów 1981, s. $115,131$.

${ }_{57}$ Rops D., A mi ot F., Apokryfy Nowego Testamentu, Londyn 1955, s. 65.

$58 \mathrm{G}$ adomski J., Malowidta ścienne z XIV w.w Czhowie, „Folia Historiae Artium” 1965 s. 18 - 19 (il. 7); Kornecki H., Małkiewiczówna H., Matopolska..., rys. 3.

$59 \mathrm{Gadom}$ ski J., Malowidta ścienne..., s. 18.

${ }^{60}$ Tamże, s. $18-19$, przypis 63 .

61 Antiphonarium z ok. 1295 r. w Bibliotece Uniwersytetu Wrocławskiego, sygn. IF $401 \mathrm{fol}$. 154 r; Kloss E., jw., s. 198 (il. 35); Karłowska-Kamzowa A., Malarstwo ślaskie..., s. 9 , 108 (il. 4); J ażd ż ew s k i K. K., Książka w klasztorze cystersów w Lubiążu na tle dziejów konwentu do 1642 roku. Przyczynek do historii kultury monastycznej na Dolnym Slasku, praca doktorska 
Pod sceną zwiastowania, w dolnej części tych pól po lewej stronie, wyobrażone jest popiersie Chrystusa w koronie drzewa rajskiego, którego trzon owinięty jest przez węża. Chrystus trzyma szarfę ze swoim monogramem; po prawej stronie ukazany jest Gedeon $\mathrm{z}$ runem i objawiającym się mu aniołem. Na szarfie znajduje się napis „Gedeon”. W wiciach roślinnych, które są zakończeniami litery w jej dolnej części, widnieją dwa popiersia: po prawej stronie prorok z napisem na szarfie „Abacuc” i po lewej (stronie) król z szarfą, na której napisano „Dawid”. U szczytu litery dwóch łuczników kieruje ostrza swoich strzał ku ptakom, które podnoszą do góry szyje, jakby czekając na zadanie ciosu.

Jezus Chrystus w koronie drzewa rajskiego nawiązuje tutaj do antytezy pawłowej Adam-Chrystus. Ojcowie Kościoła, jak to już zostało wyżej powiedziane, przenieśli tę antytezę na Ewa-Maria, mówiąc, że jak Ewa była pomocnicą Adama, tak Maria pomogła Chrysusowi ${ }^{62}$. Tę myśl powtarzali teologowie średniowiecza, jak Herman z Tournai (zm. 1147), który mówi, że Maria, nowa Ewa, jest dla nowego Adama-Chrystusa „podobną mu pomocnicą” w dziele Odkupienia ${ }^{63}$. Jest charakterystyczne, że poniżej, po tej samej stronie znajduje się popiersie Habakuka. Sw. Cyryl Jerozolimski w kazaniu zatytułowanym Ten, który przyjąt ciato $i$ stat się cztowiekiem cytuje tekst zaczerpnięty z księgi tego proroka w kontekście przyjścia Chrystusa:

Słyszałeś jak Habakuk powiedział do Pana: „Gdy się zbliżą lata, będziesz poznany, gdy przyjdzie czas, pokażesz się" (Ha 3,2). Po czym, proroku, pozna się przyjście Pana? Habakuk mówi dalej: „Będziesz poznany między dwoma życiami” (Ha 3,2). Chce do Pana powiedzieć: Gdy przyjdziesz w ciele, żył będziesz i umrzesz, ale potem wstaniesz z martwych, by żyć znowu. A z której strony Jerozolimy przyjdzie? [...] Prorok daje wyraźną odpowiedź: „Bóg przyjdzie z Temanu (a Teman znaczy południe) i Święty z cienistej góry Paran" (Ha 3,3 $)^{64}$.

Św. Proklus w kazaniu ku czci Najświętszej Dziewicy mówi o przyjściu Chrystusa w kontekście odkupienia, cytując Habakuka (Ha 2,3): W krótkim czasie przyjdzie niezawodnie i nie opóźni się ${ }^{65}$. Sw. Ildefons z Toledo w traktacie $O$ wieczystym dziewictwie Najświętszej Maryi Panny także mówiąc o Zbawicielu i pierwszym przyjściu Chrystusa, posługuje się tekstem zaczerpniętym z Habakuka $(3,13)$ : Wyszedteś na ocalenie swego ludu, na wybawienie swych wybranych ${ }^{66}$.

Wszyscy wyżej zacytowani Ojcowie Kościoła posługują się tekstami Habakuka, aby wskazać, że to pierwsze przyjście ma charakter zbawczy, a Ten, który ma zbawić ludzkość, będzie cierpiał. Św. Hieronim, którego pisma były

pisana pod kierunkiem dr hab. Kazimiery Maleczyńskiej, Wrocław 1984, Uniwersytet Wrocławski, Wydział Filologiczny, s. 226, 158, 275.

${ }^{62}$ Flor k ow ski E., jw., s. 64 . Wyraża tę myśl Tertulian (Adv. Marc. II 4, PL 2, 288), zależny od Ireneusza, bpa Lyonu.

${ }_{63}$ Bialic D., jw., s. 249.

${ }^{64}$ Ojcowie Kosciota greccy i syryjscy..., s. 90.

65 Tamże, s. 108.

66 Ojcowie Kościota łacińscy..., s. 176. 
punktem wyjścia dla średniowiecznych interpretacji proroctw Habakuka, powiada, że Habakuk zapowiedział śmierć krzyżową Chrystusa. O przytoczonym na patenie kaliskiej wersecie z rozdziału 3. (cornua in manibus eius. Ibi abscondita est fortitudo eius) powiada, że wyjaśnia on śmierć krzyżową Chrystusa ${ }^{67}$. Tak więc Chrystus w koronie drzewa rajskiego i proroctwo Habakuka stanowią pewną całość, w której zaakcentowane jest drzewo rajskie i drzewo krzyża oraz wszystkie związane z nimi konsekwencje.

Runo Gedeona, który rozmawia z aniołem, jest wydarzeniem starotestamentalnym, wiązanym z grupą tekstów Pisma Świętego. Kościół w liturgii, a różni Ojcowie Kościoła i pisarze Kościelni w swych dziełach stosują je do Matki Najświętszej ${ }^{68}$, chociaż sens ich przystosowany nie jest sensem Pisma Świętego. Maria jest runem Gedeona jedynie tylko rosą niebieską zwilżonym, gdy cała wokół ziemia pozostała nietkniętą ${ }^{69}$. P. Skubiszewski, omawiając czarę włocławską i zawartą na niej scenę z runem Gedeona, krótko podaje genezę tego przedstawienia. W związku z zachodnioeuropejskimi, romańskimi przykładami mówi, że połączona jest ona często na zasadzie typologicznej z tematem zwiastowania Marii. Przykładem jest iluminacja na fol. $7 \mathrm{v}$ dolnosaskiego psałterza, połączonego z kalendarium (Landsdowne Ms. 381, British Museum w Londynie, trzecia ćwierć XII w.). Znajduje się ona na odwrocie karty zawierającej kalendarz na grudzień i przedstawia w środku zwiastowania Marii Mojżesza pod krzakiem gorejącym i Gedeona przed rosą spływającą na runo. W narożach cztery popiersia proroków, którzy zapowiedzieli nadejście Mesja$\mathrm{sza}^{70}$. Niestety, nie ma w tej scenie anioła jako wysłannika Bożego do przeprowadzenia rozmowy z Gedeonem. Występuje on oraz runo na patenie kielicha z Trzemeszna (tzw. Dąbrówki), przy czym Gedeon przedstawiony jest na niej w czasie młócenia zboża, a cała scena powiązana jest z przedstawieniem Ukrzyżowania jako głównym tematem pateny ${ }^{71}$.

Korona na głowie Dawida podkreśla jego królewskość i dynastię. Od chwili proroctwa Natana wiązane były z nią nadzieje Izraela ( $2 \mathrm{Sm} .7,12-16)$. Dawid dla Izraelity pozostaje zawsze typem Mesjasza, który miał się narodzić $\mathrm{z}$ tego pokolenia. Od czasów Dawida przymierze Boga z ludem zawierane było zawsze przez króla (Syr 47,2 - 11), a tron Izraela był tronem Dawida (Iz. 9,6; Łk. 1,32). Zwycięstwa Dawida zapowiadały tryumfy, jakie Mesjasz pełen Ducha Swiętego, który spoczął na Synu Jessego (1 Sm. 16,13; Iz. 11,1 - 9), odniesie nad niesprawiedliwością. A gdy się wypełniły czasy, Chrystus został nazwa-

${ }^{67} \mathrm{H}$ ie r o $\mathrm{n}$ i m, Comentariorum in Abacuc prophetam libri II, PL 23, szp. 1312 - 1314; S k u bis zewski P., Patena kaliska..., s. 207.

68 Od Orygenesa koncepcję typologiczną runa przyjęli Ojcowie lacińscy: Ambroży, Augustyn, Izydor, Beda, Rabanus, Maurus; por. Sk u biszewski P., Czara Wtoctawska, [w:] Studia nad spuścizna Wschodu w sztuce wczesnego średniowiecza, Poznań 1965, s. 118 (przypis 12).

${ }^{6} \mathrm{~N}$ icolas A., Dą brow s k i E. Zycie Maryji Matki Bożej, Warszawa 1954, s. 32; W in i ars k i K., Matka Najświętsza w Piśmie Świętym, [w:] Gratia plena, s. 39.

70 Sku biszew ski P., Czara Wtoctawska..., s. 86.

71 Tamże, s. 75, 77 (il. 42); tenże, Programy obrazowe..., s. 10 (il. 4, 6). 
ny Synem Dawida (Mt. 1,1) ${ }^{72}$. Dwaj dzicy ludzie (scythe people) i ptak, stojący nad literą, przez symbolikę śmierci, z nimi związaną, zdają się podkreślać myśl drzewa życia, drzewa śmierci, upadku i ofiary ${ }^{73}$.

\section{WYPEŁNIANIE PROROCTW STAREGO TESTAMENTU}

W Codex aureus (w Bibliotece Kapitulnej w Gnieźnie, sygn. ms la fol. 30 v) z lat ok. 1085 - 1090 (il. 13) ${ }^{74}$; w kodeksie lubińskim z legendą św. Jadwigi; na malowidle ściennym z ok. 1360 r. w kościele parafialnym p.w. Wszystkich Swiętych w Strzelcach pod Sobótką ${ }^{75}$; na poliptyku grudziądzkim ${ }^{76}$ i wielu przedstawieniach z XIV i XV w., jak również z początku XVI wieku, Maria trzyma w ręce książkę lub książka leży na pulpicie otwarta.

Ustawienie pulpitu z książką sięga już czasów karolińskich i ottońskich, jak podaje G. Schiller ${ }^{77}$. Na drzwiach drewnianych w kościele Najświętszej Marii Panny na Kapitolu w Kolonii (połowa XI w.) leży ona zamknięta na pulpicie. W praskim ewangeliarzu koronacyjnym Maria trzyma ją w ręce (również zamkniętą) ${ }^{78}$. Podobnie, na północnym lewym portalu katedry w Chartres, Maria trzyma książkę w ręce, a na prawym tympanonie zachodniej fasady tej samej katedry (1150 - 1155), książka leży otwarta na podłodze pomiędzy Marią i Gabrielem. We francuskiej rzeźbie katedralnej jest to jedyny dodatkowy element ikonograficzny, oprócz krzesła lub tronu stojącego za Marią, a występującego w scenie zwiastowania ${ }^{79}$.

W karolińskim wierszu Otfryda pt. Kryst jest mowa, że Maria podczas zwiastowania czytała Psałterz ${ }^{80}$, a bizantyńskie zbiory kazań od VIII do X wie-

${ }^{72}$ Stownik teologii biblijnej, Poznań-Warszawa 1982, s. $201-203$; Hall J., Dictionary of Subjects and Symbols in Art, London 1987, s. 92.

${ }^{73} \mathrm{Hall}$ J., jw., s. 94.

${ }^{74}$ Sztuka polska przedromańska i romańska..., s. 250, 692; Katalog zabytków sztuki w Polsce, t. 5 z. 3 s. 46 (fig. 197).

75 Dobrowolski T., jw., s. 133 - 134 (il. 62); Karłowsk a-Kamzowa A., Ślask, [w:] Gotyckie malarstwo ścienne w Polsce..., s. 82-84.

76 Dobrzeniecki T., Malarstwo tablicowe, s. 87 - 100 (il. 3202); Lab u da A., Malarstwo tablicowe państwa krzyżackiego drugiej połowy XIV wieku, [w:] Malarstwo gotyckie na Pomorzu Wschodnim..., s. $75-81$ il. 41.

$77 \mathrm{Sch}$ ille r G., jw., s. 54. Począwszy od XI wieku wrzeciono w ręce Marii jest często zastępowane przez książkę, a następnie od XII w. przez zwój pisma.

${ }_{78}$ Tamże, s. 52.

${ }^{79} \mathrm{Schill}$ r G., jw., s. 63; Katze nelle n be rge n A., The Sculptural Programs of Chartres Cathedral, Baltimore 1959, il. 10, 54; D e kn a te l F. B., The Thirteenth Century Gothic Sculpture of the Cathedrals of Burgous and Leon, „The Art Bulletin” $17: 1935$ z. 3 s. $298-387$ (il. 41, 54, 89, 94 - 95); Katedry w Reims i Amiens; por. R. v a n M a rle, L'Annunciation dans la sculpture monumentale de Pise et de Sienne, „La Revue de L'Art Ancien et Moderne” 65 : 1934 s. 117, 118 (il. $4-5$ ).

${ }^{80}$ Do malarstwa wprowadził ten motyw Duccio, wkładając w ręce Marii książkę w miejsce wrzeciona; por. G. Mille t, Recherches sur l'iconographie de l'Evangile aux XIV, XV et XVIe siècles d'apres les monuments de Mistra, de la Macedoine et du Month-Athos. Dessines de Sophie Millet, Paris 1960, s. 83. 
ku przypisują Marii mądrość starożytnej bogini Ateny ${ }^{81}$. W pseudoewangelii Mateusza jest napisane, że „nie było nad Nią ani jednej bardziej ochoczej w czuwaniu, bardziej biegłej w znajomości Prawa Bożego, bardziej przejętej pokorą, piękniej śpiewającej psalmy Dawida" ${ }^{2}$. Teologowie średniowieczni widzieli w Marii Mistrzynię wszystkich siedmiu sztuk wyzwolonych, które prowadzą do poznania Boga i przypisują Jej siedem darów Ducha Świętego oraz wynoszą Ją jako Matkę ponad wszelkie stworzenia ${ }^{83}$. W ten sposób Maria, według ówczesnego pojęcia, nadawała się na przyjęcie Chrystusa. Mistyka przygotowanie do tego wyniesienia widzi w Jej kontemplacji i Jej modlitwie. Medytacje pseudo-Bonawentury głoszą, że Maria czytała właśnie księgę Izajasza, gdy zjawił się Jej anioł. Z tej przyczyny na obrazach Maria jest wyobrażana z otwartą książką w miejscu, w którym można odczytać Iz. 7, $14^{84}$.

Tertulian w traktacie $O$ ciele Chrystusa pyta, czy „Chrystus wziął ciało z Dziewicy". Przede wszystkim należy podkreślić porządek rozmowy, który kierował dziewiczym narodzeniem Syna Bożego. Sprawca nowych narodzin musiał w nowy sposób się narodzić. Pan przez Izajasza zapowiedział, że da znak wieszczy tych narodzin. Jaki to znak? „Oto Panna pocznie i porodzi” (Iz. 7,14). Panna więc poczęła i porodziła Emmanuela, tj. Boga z nami. Na tym polegają nowe narodziny, że człowiek rodzi się w Bogu, odkąd Bóg narodził się w człowieku, przyjąwszy ciało ze starego nasienia bez tego nasienia. Pan tak uczynił, aby przekształcić ciało przez nowe duchowe nasienie i oczyścić je usunąwszy z niego nieczystości. Lecz dawnym symbolem całej tej nowości, jak we wszystkim, są zgodne z porządkiem rozmowy narodziny człowieka dla Pana za pośrednictwem dziewicy ${ }^{85}$.

Ojcowie Kościoła, a potem teologowie i poeci, aby wyrazić cud poczęcia Chrystusa przez Najświętszą Marię Pannę, posługiwali się symbolami, które były zrozumiałe w tamtym czasie, mimo że niekiedy nie były ortodoksyjne, jak na przykład conceptio per aurem. Posługiwali się Starym Testamentem, szukając typów: runa Gedeona, różdżki Aarona czy zamkniętych drzwi ezechielowych, przez które tylko Pan mógł przejść. Mówiąc o Chrystusie używali porównania ze światłem czy ogniem, które Maria otrzymała i porodziła $^{86}$.

Trzy kodeksy: Graduale ufundowane dla klarysek w Gnieźnie przez opatkę Katarzynę z Zagajewa i kanonika Mikołaja Goszczyńskiego (il. 14) ${ }^{87}$, Antyfo-

${ }^{81}$ Schille r G., jw., s. 52.

82 A miot F., Rops D., jw., s. $54-55$. pis 38).

${ }^{83}$ Albert Wielki i Thierry z Chartres, połowa XII w.; por. Schille r G., jw., s. $52-53$ (przy-

${ }^{84}$ Tamże, s. 53 (il. 104).

85 Ojcowie Kościoła łacińscy..., s. 21.

$86 \mathrm{Me}$ is s M., Light as Form and Symbol in Some Fifteenth Century Paintings, „The Art Bulletin" $27: 1945$ s. $176,177$.

87 Archiwum Kapitulne Katedry Gnieźnieńskiej, sygn. Ms. 170 fol. I; Ma cie jewska A., Graduat klarysek gnieźnieńskich z 1418 r., Poznań 1958 (rkps w Zakładzie H.S.UAM w Poznaniu); Katalog zabytków sztuki w Polsce, t. 5 z. 3 fig. 271. 
narz bpa Zbigniewa Oleśnickiego (KP 47) (il. 15) ${ }^{88}$ i Antyfonarz $n r 1$ w kościele Bożego Ciała w Krakowie (il. 16) ${ }^{89}$ mają element wspólny, ponieważ scena zwiastowania jest w nich związana z proroctwem Izajasza.

Antyfonarz $\mathrm{nr} 1 \mathrm{z}$ kościoła Bożego Ciała i Antyfonarz Zbigniewa Oleśnickiego mają ten sam tekst antyfon do psalmów na pierwsze nieszpory na święto Zwiastowania Najświętszej Marii Panny (Antyfonarz $n r$ 1) i I niedzielę Adwentu (Antyfonarz Oleśnickiego). Pierwsza antyfona mówi: A diebus antiquis nos audivimus exore prophetarum quia ipse est qui venturus est cuius virga floruit de radice Yesse habens imperium regni super omnia regna mundi. Antyfona ta jest oparta na tekście Izajasza 11,1: Egredietur virga de radice Yesse et flos de radice eius ascendet. Na miniaturze antyfonarza Oleśnickiego zacytowany jest także wiersz Iz. 7,14, znajdujący się na wstędze trzymanej przez tegoż proroka: Ecce virgo concipiet et pariet filium. Na miniaturze antyfonarza $\mathrm{nr} 1 \mathrm{w}$ kościele Bożego Ciała Maria wskazuje prawą ręką na tekst: Ecce virgo concipiet et pariet filium, zawarty w książce leżącej na pulpicie.

K. M. Birkmeyer, omawiając motyw arkady w niderlandzkim malarstwie, twierdzi, że pełne znaczenie iluminacji nie może być odkryte bez łączności $\mathrm{z}$ tekstem je ilustrującym. Zwykle miniatura powtarza w malarskiej formie napisany tekst. Ale często, przynajmniej w XIV wieku, miniatura znaczeniowo rozszerza się bardziej niż tekst przez dodanie do niej treści, które w malarskiej formie czysto analogicznie lub typologicznie odnoszą się do napisanego tekstu. W tych wypadkach miniatura sama staje się symbolem i zasadniczą sceną, a nie ilustracją ${ }^{90}$.

Jakie jest odniesienie naszej miniatury w Antyfonarzu w kościele Bożego Ciała do tekstu wspomnianej antyfony, zawartej na tej samej stronie Antyfonarza? Tło dla inicjału $A$ i osób zwiastowania stanowi pokryta złoceniem płaszczyzna prostokąta. Światło i złoto w apsydzie kościoła, według Rabana Mau$\mathrm{ra}$, są atrybutem boskości i zarazem najwyższym pięknem ${ }^{91}$. Ta symbolika złota funkcjonowała przez całe średniowiecze ${ }^{92}$. Inicjał $A$, który jest pierwszą literą antyfony, został wpisany w złoty prostokąt tła i stanowi arkadę dla namalowanego portyku z pulpitem, Marii i zwiastującego anioła. Litera ta więc łączy tekst z tym, co jest przedstawione wewnątrz niej i pełni rolę arkady zapoczątkowującej pewną nową rzeczywistość ${ }^{93}$. Litera jest barwy winnej, podob-

${ }^{88}$ Archiwum Kapitulne Katedry Krakowskiej na Wawelu w Krakowie, sygn. KP 47 fol. 1; Miod ońs k a B., Iluminacje krakowskich rękopisów z pierwszej połowy w. XV w Archiwum Kapituty Metropolitalnej na Wawelu, Kraków 1961, s. 30 - 44 (il. 18).

${ }_{89}$ Sygn. Nr 1 fol. 222 r, P i én k ow s k a H., Sredniowieczna pracownia miniatorska w Krakowie, „Rocznik Krakowski” 32 : 1951 s. 45 - 58 (il. 8).

90 B irkme ye r K.M., The Arch Motif in Netherlandisch Painting of the Fifteenth Century, „The Art Bulletin” $43: 1961$ z. 1 s. 12.

${ }_{91} \mathrm{R}$ aban Maur, De universo III; por. Rze pińs k a M., Historia koloru $w$ dziejach europejskiego malarstwa, Kraków 1983, s. 166 (przypis 24).

92 Rzepińska M., jw., s. 117 n.

$93 \mathrm{~W}$ miniaturze do czasów Jean Bondal arkada używana była dla zamknięcia obrazu w jedną całość i była czymś zewnętrznym dla samej sceny, którą ograniczała. Bondal uczynił następny 


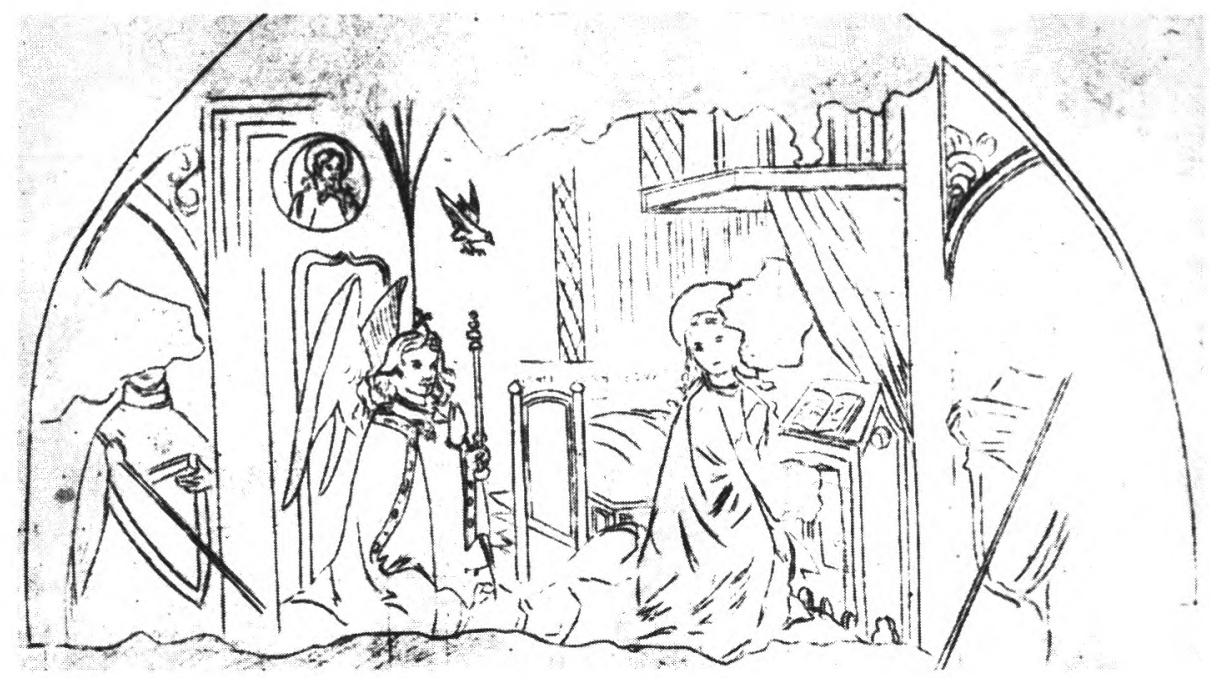

1. Malowidło ścienne (nieistniejące) z lat ok. 1500-1510 w krużganku kościoła oo. Dominikanów w Krakowie.

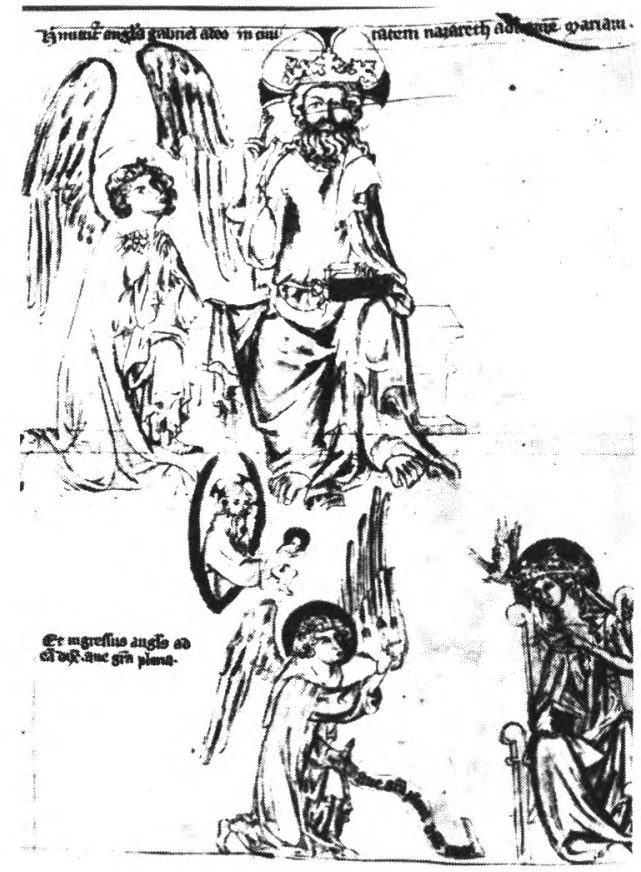

2. Kodeks lubiński (z legendą o św. Jadwidze) z 1353 r., przechowywany w John Paul Getty Museum w Malibu (fol. 167 v). 


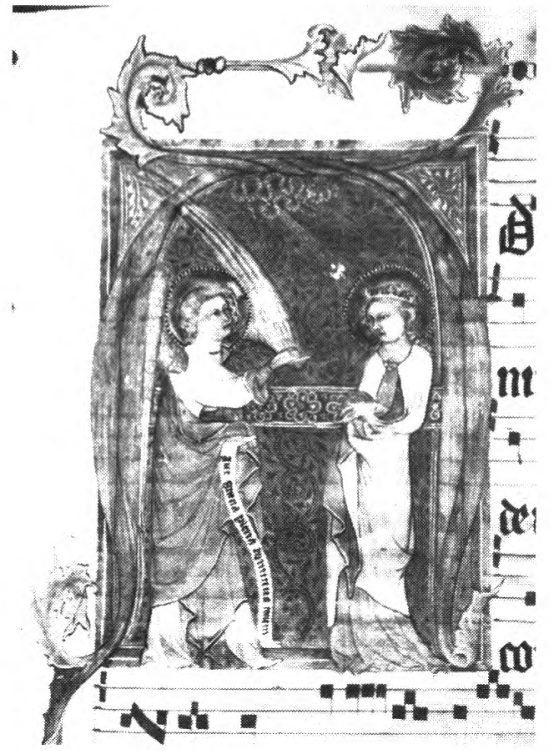

3. Graduał ołbiński z 1362 r. (Wrocław, BU, sygn. IF 423, fol. 3 r).

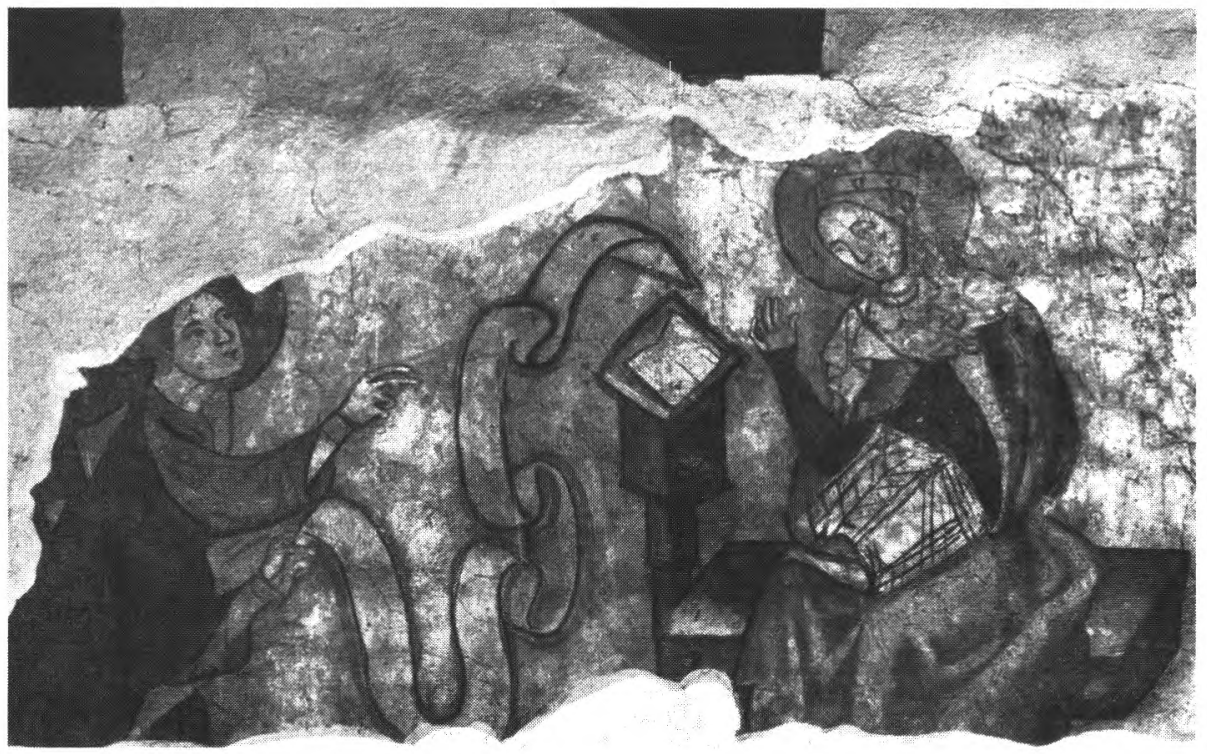

4. Polichromia z ok. 1390 r. w kościele św. Kosmy i Damiana w Okoninie. Fot. J. Langda. 
5. Witraż w kościele Mariackim w Krakowie (k. XIV w.).
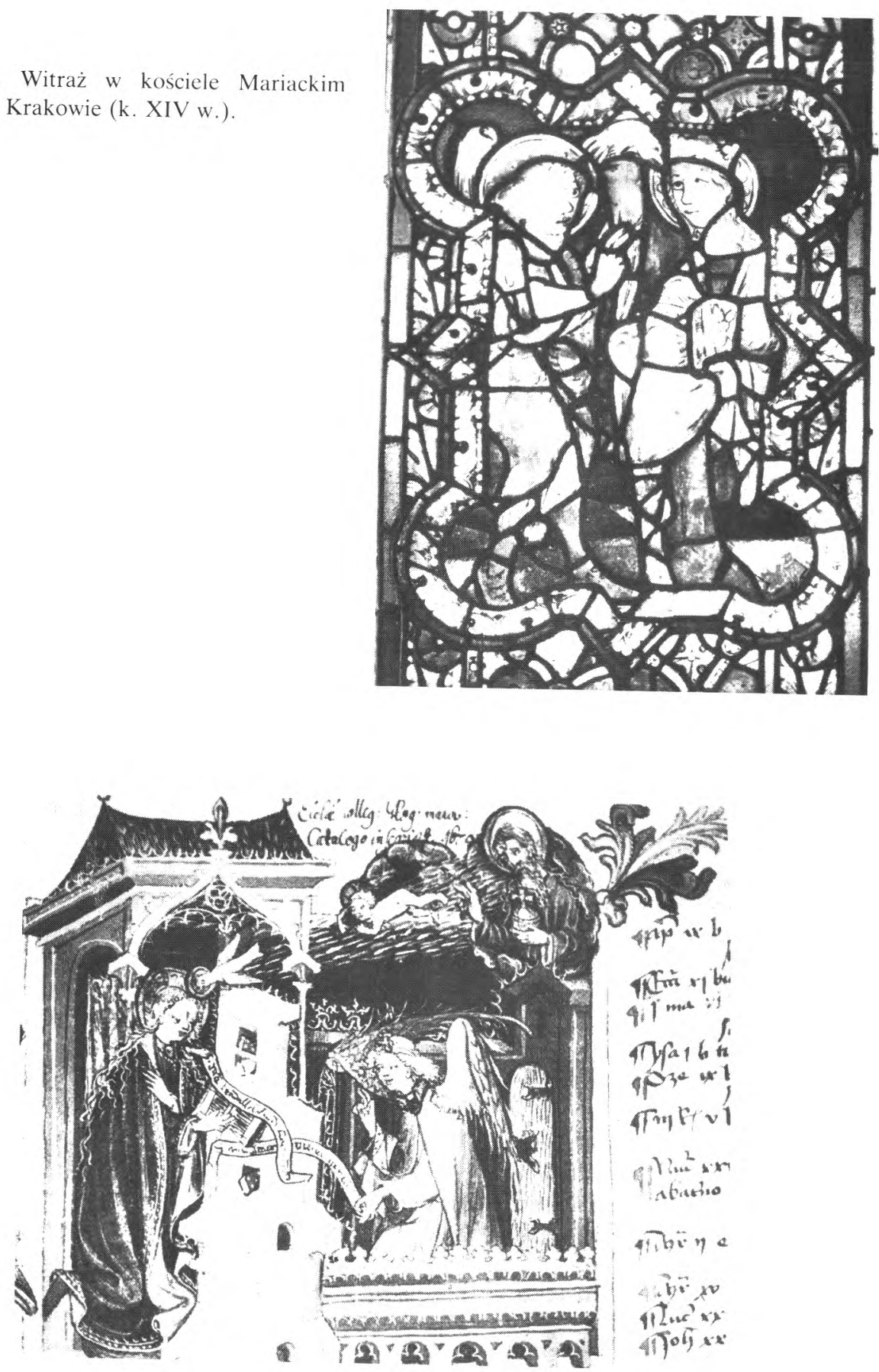

6. Concordantiae Bibliorum (1472 r.) Mateusza z Oleśnicy (Wrocław, BU, sygn. IF 88, fol. Ir). Fot. za E. Kloss. 


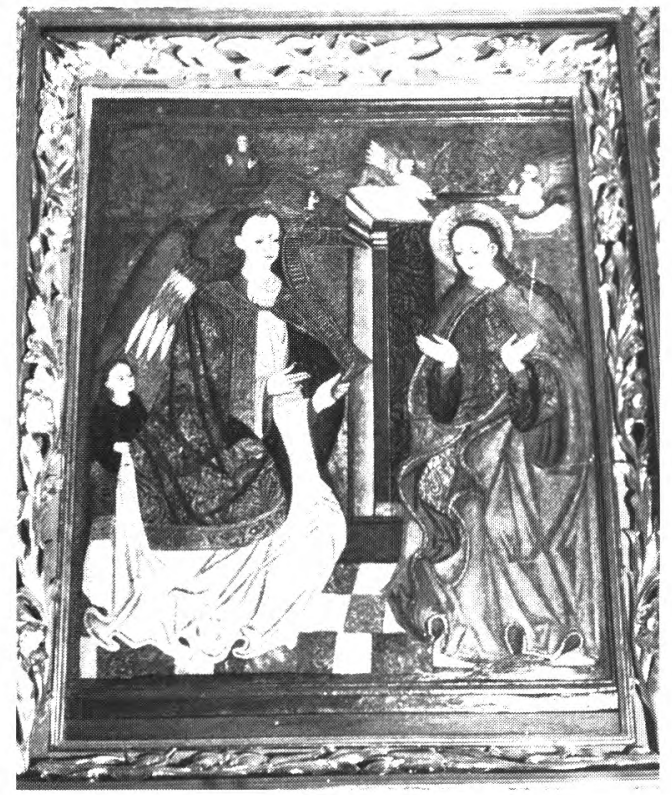

7. Obraz Zwiastowania z ok. 1500 r. w kościele parafialnym w Zagórzu k. Sanoka. Fot. J. Sajdera.

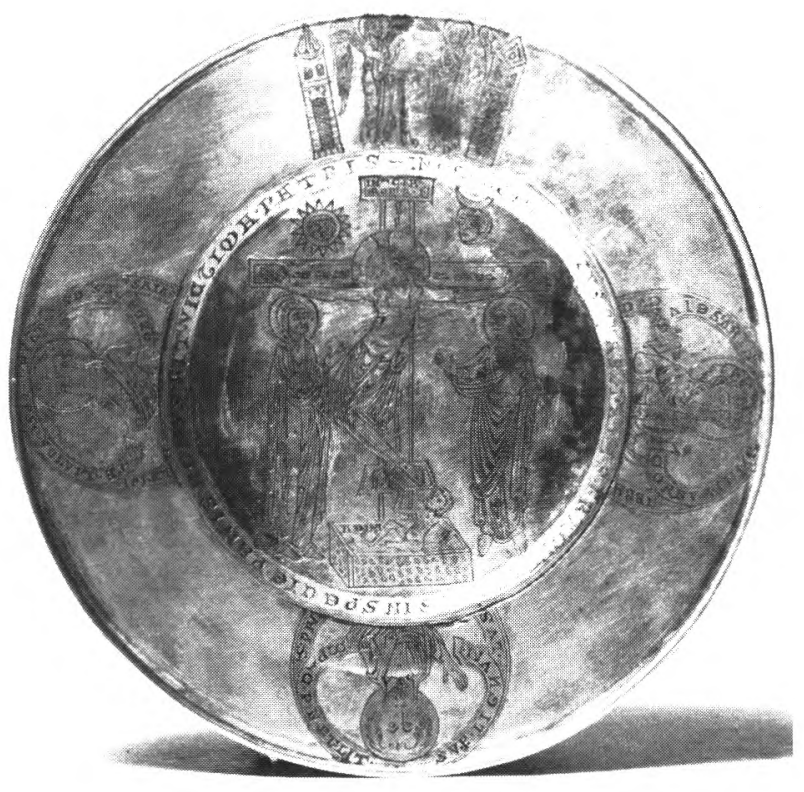

8. Tzw. patena Mieszka Starego z ok. 1193 r. w kolegiacie Wniebowzięca P. Marii w Kaliszu. Fot. J. Langda. 


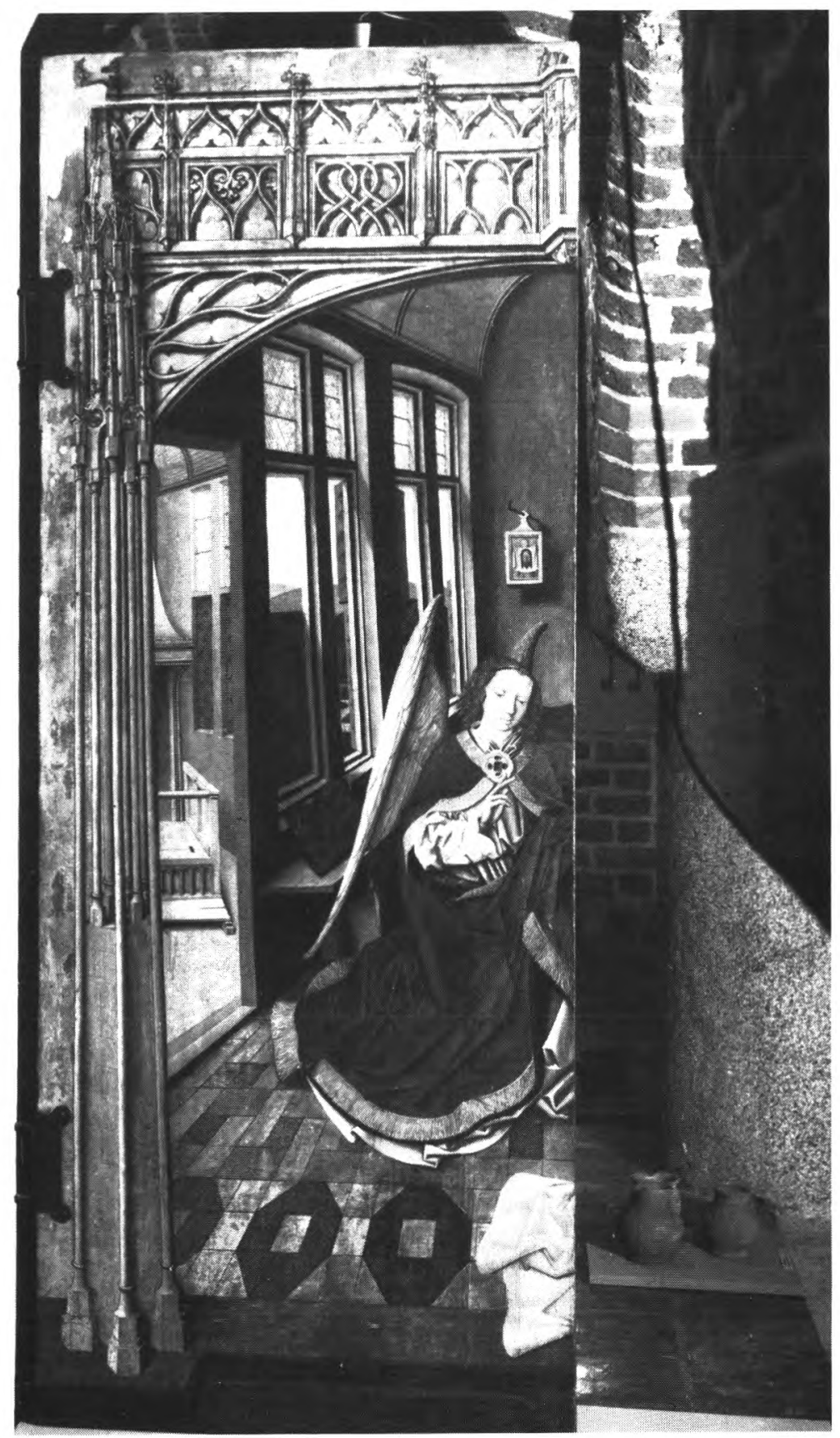

9. Skrzydło ołtarzowe z 1480 r. w kościele Sw. Jana w Toruniu. Fot. W. Górski. 


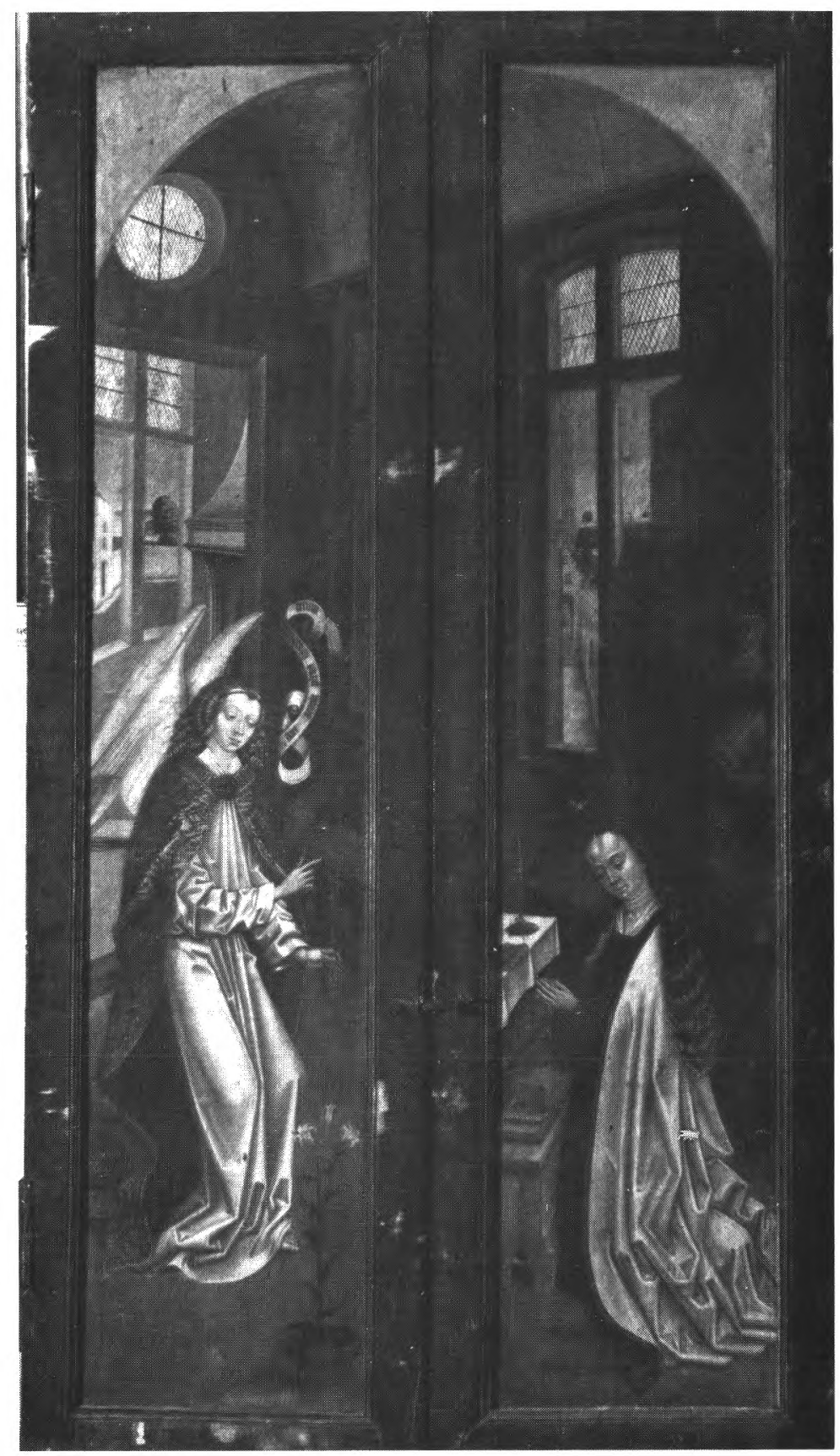

10. Rewersy skrzydeł pentaptyku z lat pomiędzy 1485 a 1490, ufundowanego przez Jana Ferbera z kościoła Mariackiego w Gdańsku. 

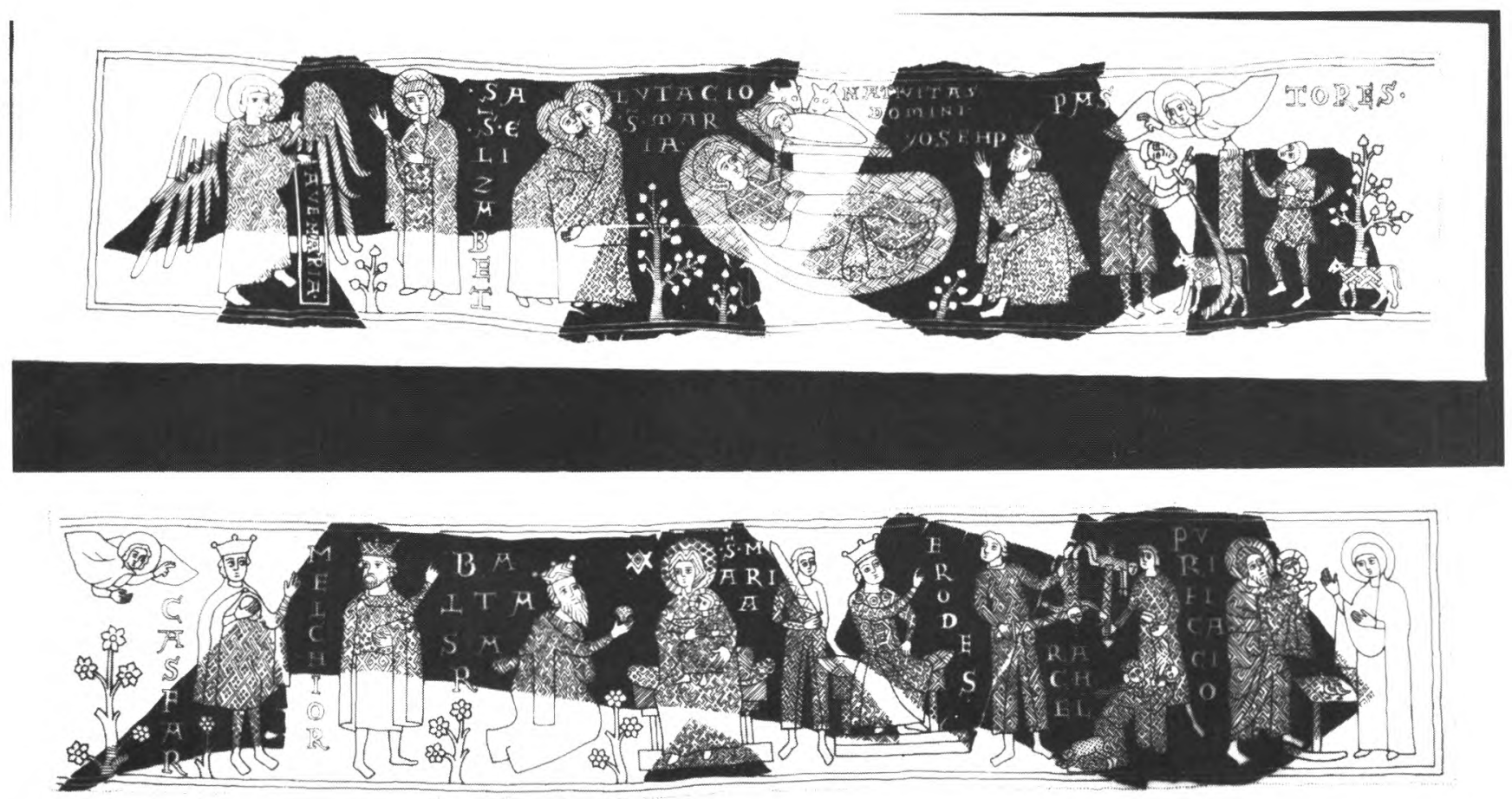

11. Kolumna ornatu św. Jadwigi z Henrykowa, z poł. XIII w., w Muzeum Archidiecezjalnym we Wrocławiu. Fot. J. Langda. 


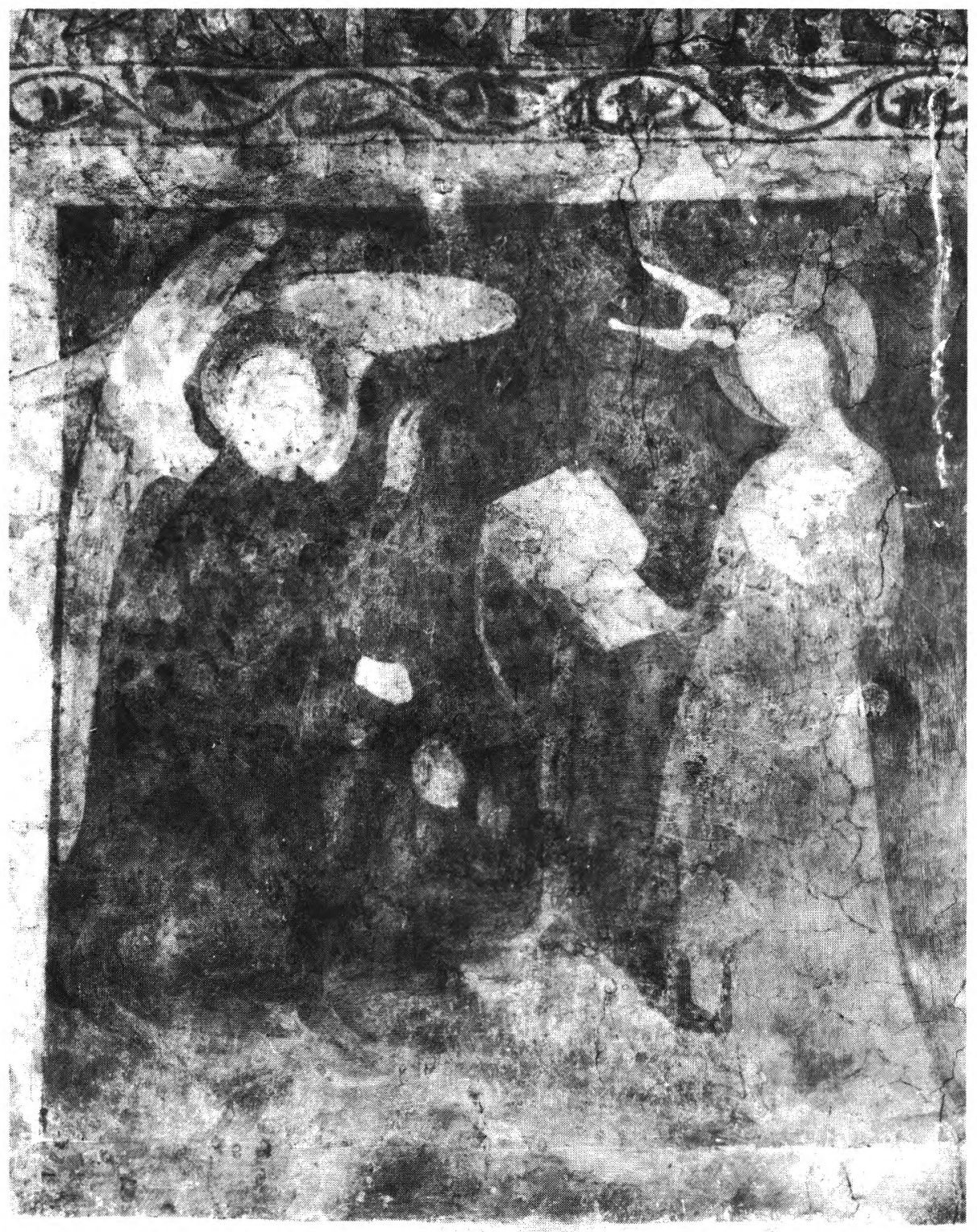

12. Malowidło ścienne z XIV w. w kościele parafialnym w Czchowie. Fot. St. Stępniewski. 


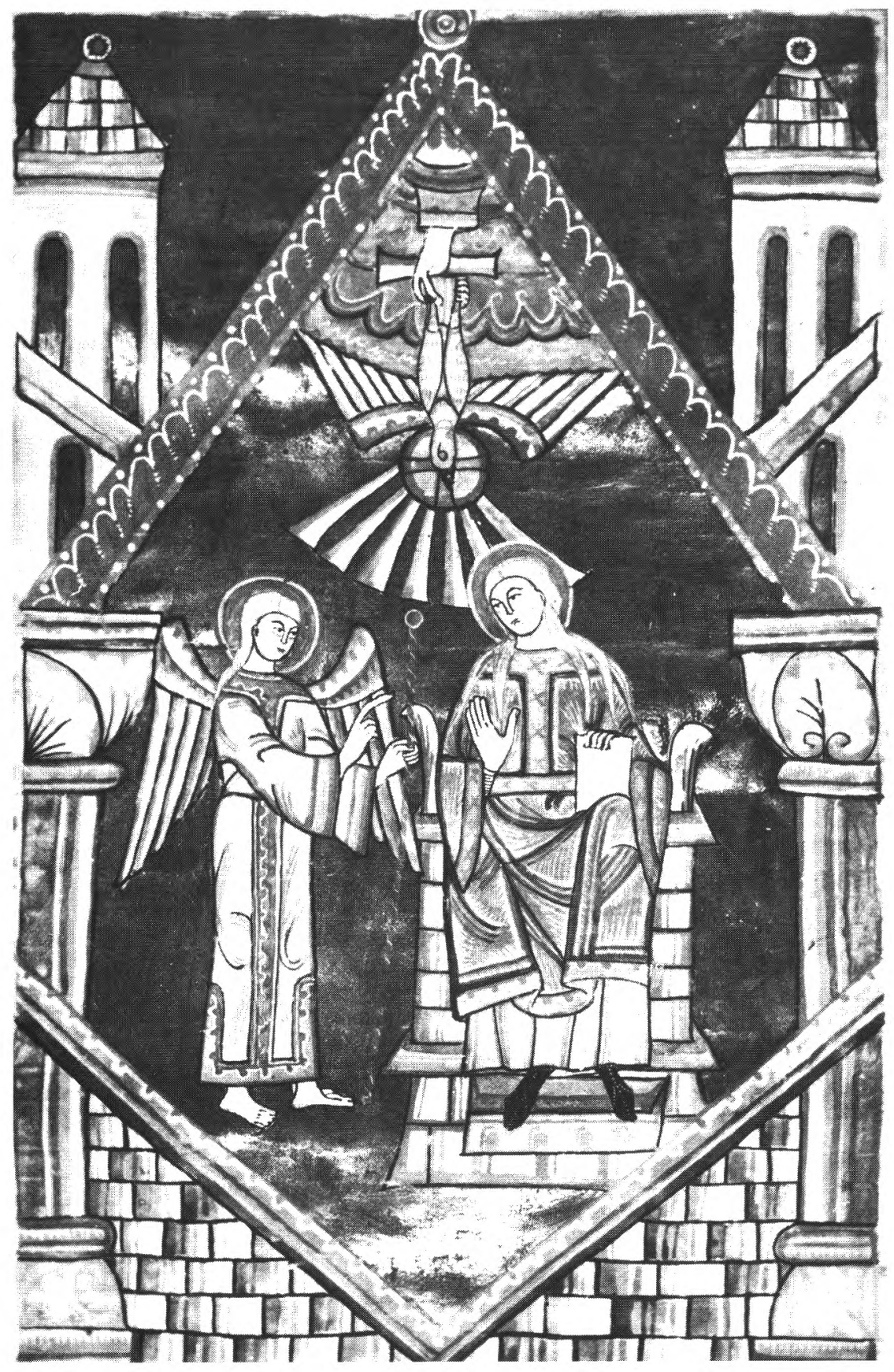

13. Tzw. „Codex aureus”, z ok. 1085-1090 r. (Gniezno, Biblioteka Kapitulna, sygn. Ms la, f. 30 v). Fot. J. Nowicki. 


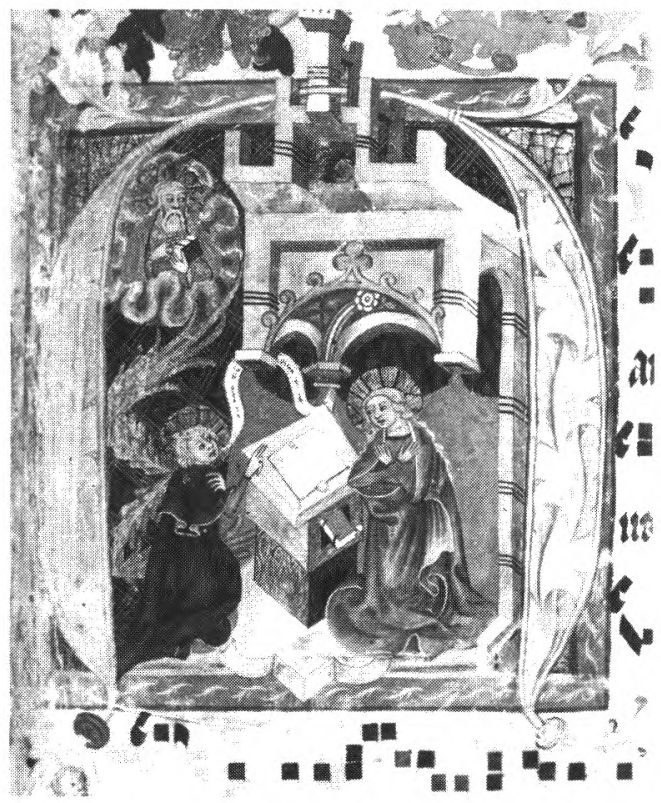

14. Graduale z 1418 r. ufundowane dla klarysek w Gnieźnie (Gniezno, Biblioteka Kapitulna, sygn. Ms 170).

15. Antiphonarium de tempore, $\mathrm{z}$ lat po 1423 r., ufundowane przez bpa Z b. Oleśnickiego (Archiwum Kapitulne Katedry Krakowskiej, sygn. KP 47, fol. 1). Fot. St. Stępniewski.

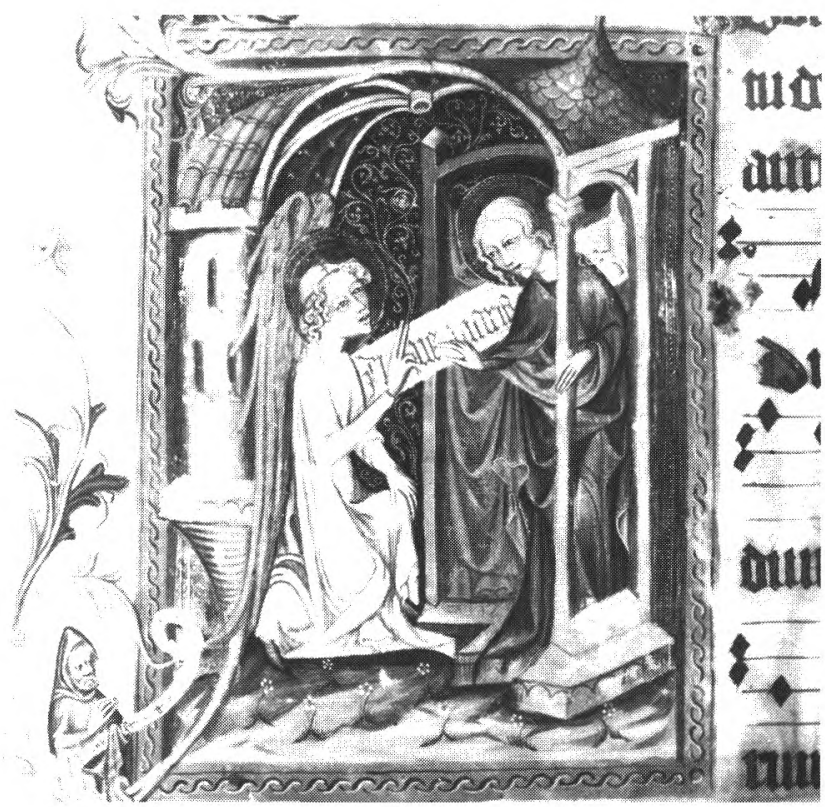


16. Antiphonarium z lat 1405-1422 w klasztorze przy kościele Bożego Ciała w Krakowie (sygn. Nr 1, fol. 222 r.). Fot. J. Langda.
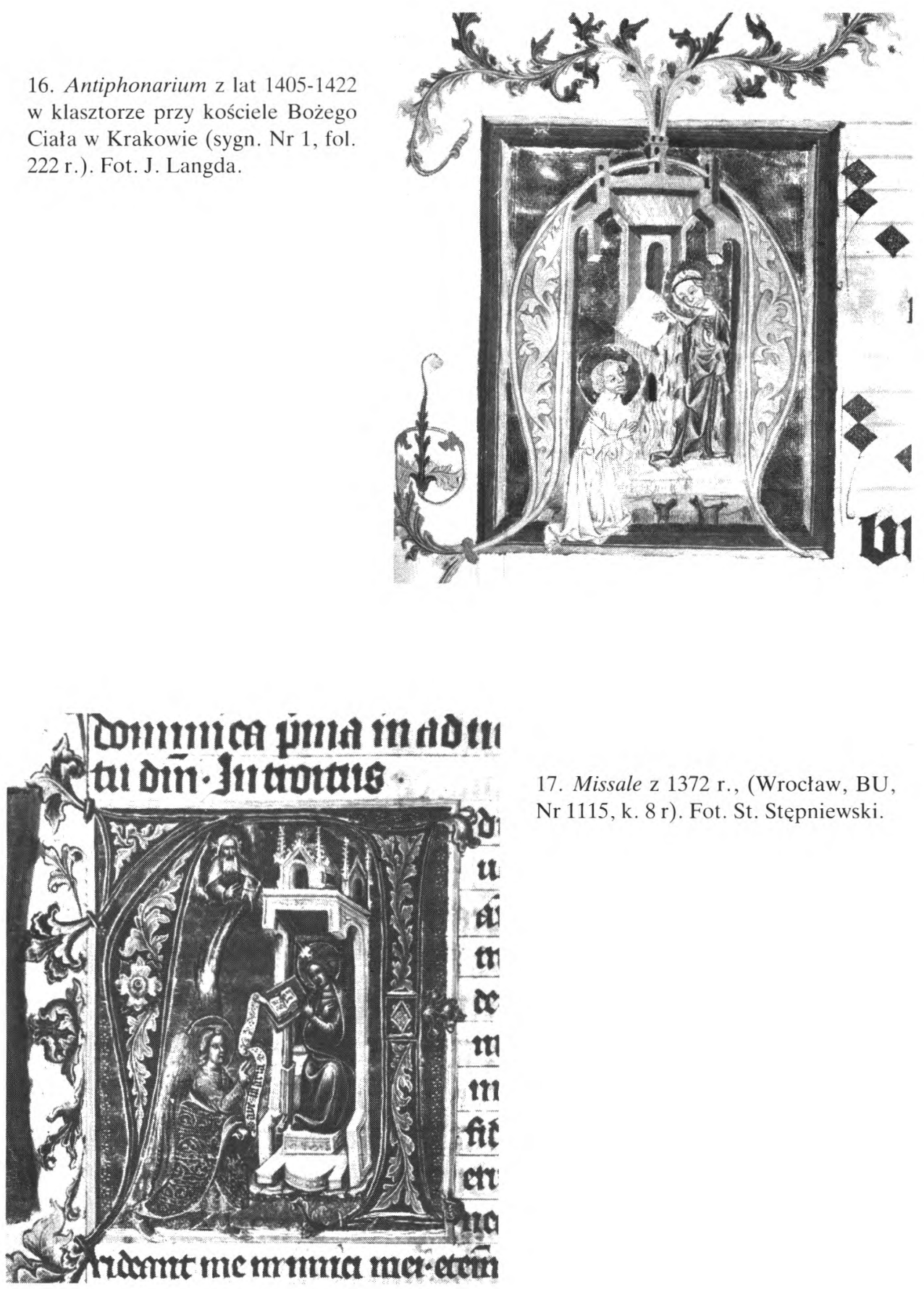

17. Missale z 1372 r., (Wrocław, BU, Nr 1115, k. 8 r). Fot. St. Stępniewski. 


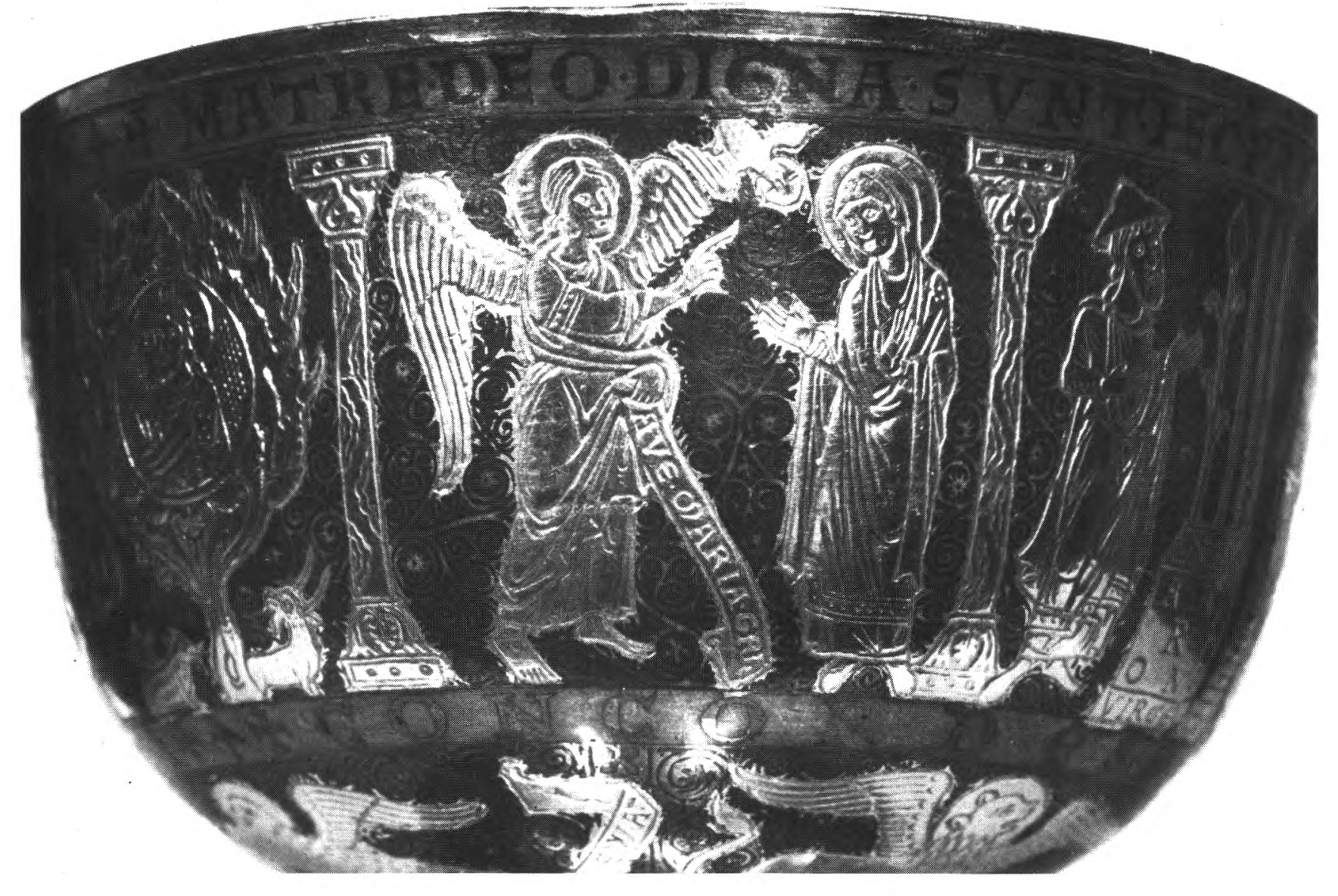

18. Tzw. kielich Dąbrówki z 3/4 ćw. XII w., w skarbcu Bazyliki Prymasowskiej w Gnieźnie. Fot. J. Langda. 


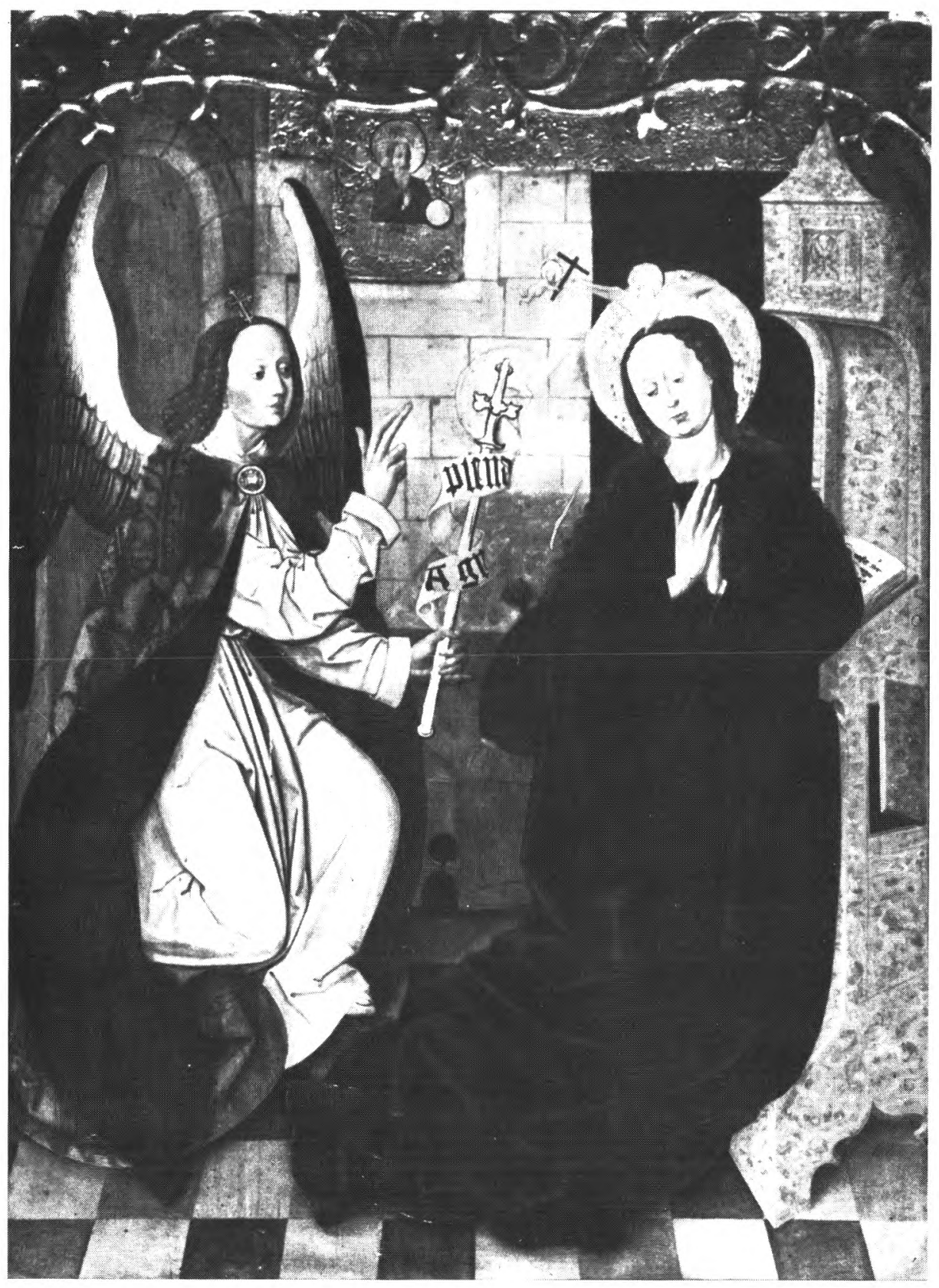

19. Kwatera tryptyku z 1491 r. w kościele Wniebowzięcia Najśw. Marii Panny w Książnicach Wielkich. Fot. W. Wolny. 


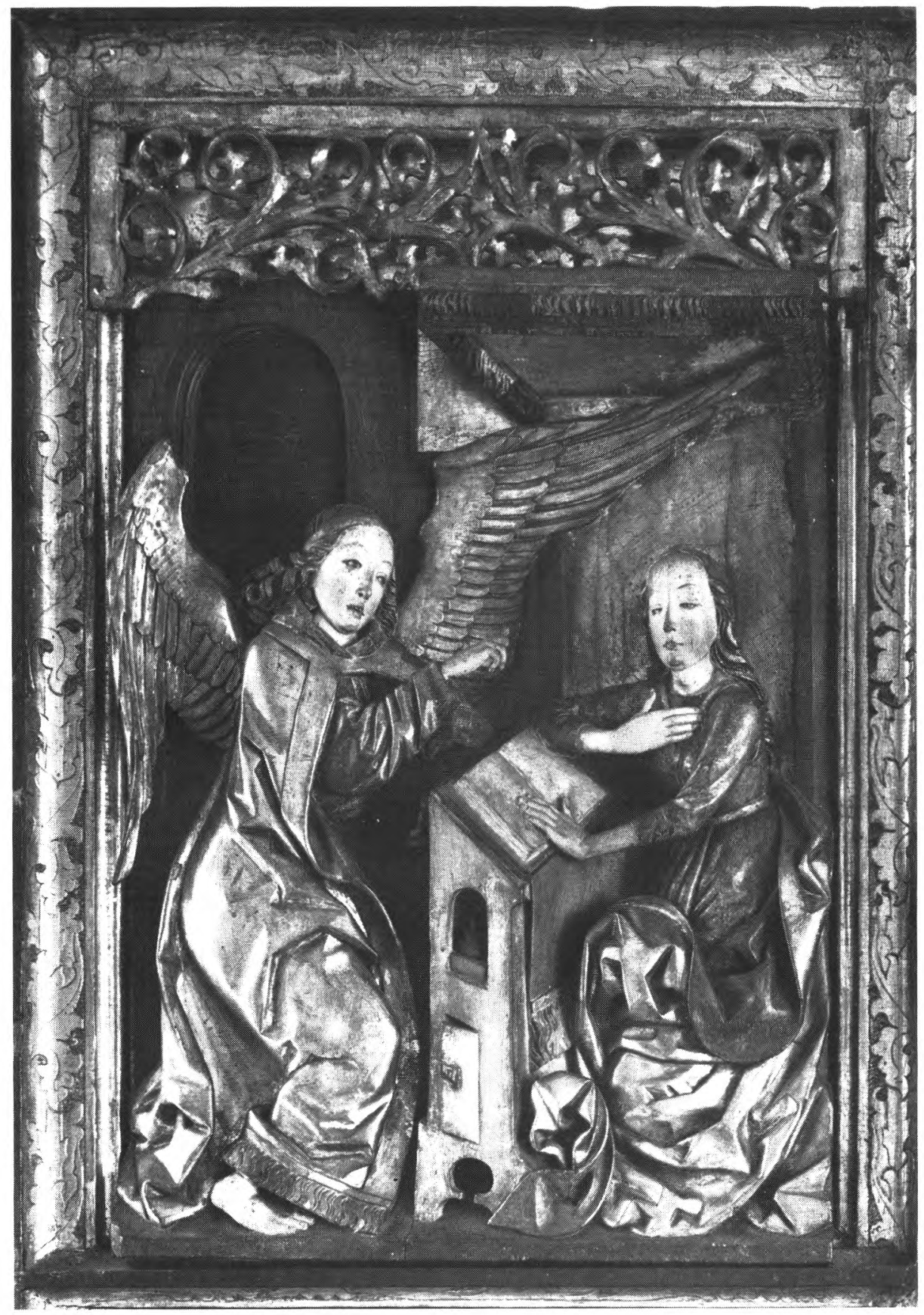

20. Kwatera ołtarza z ok. 1500 r. z Lusiny, w Muzeum Narodowym w Krakowie. Fot. St. Stępniewski. 


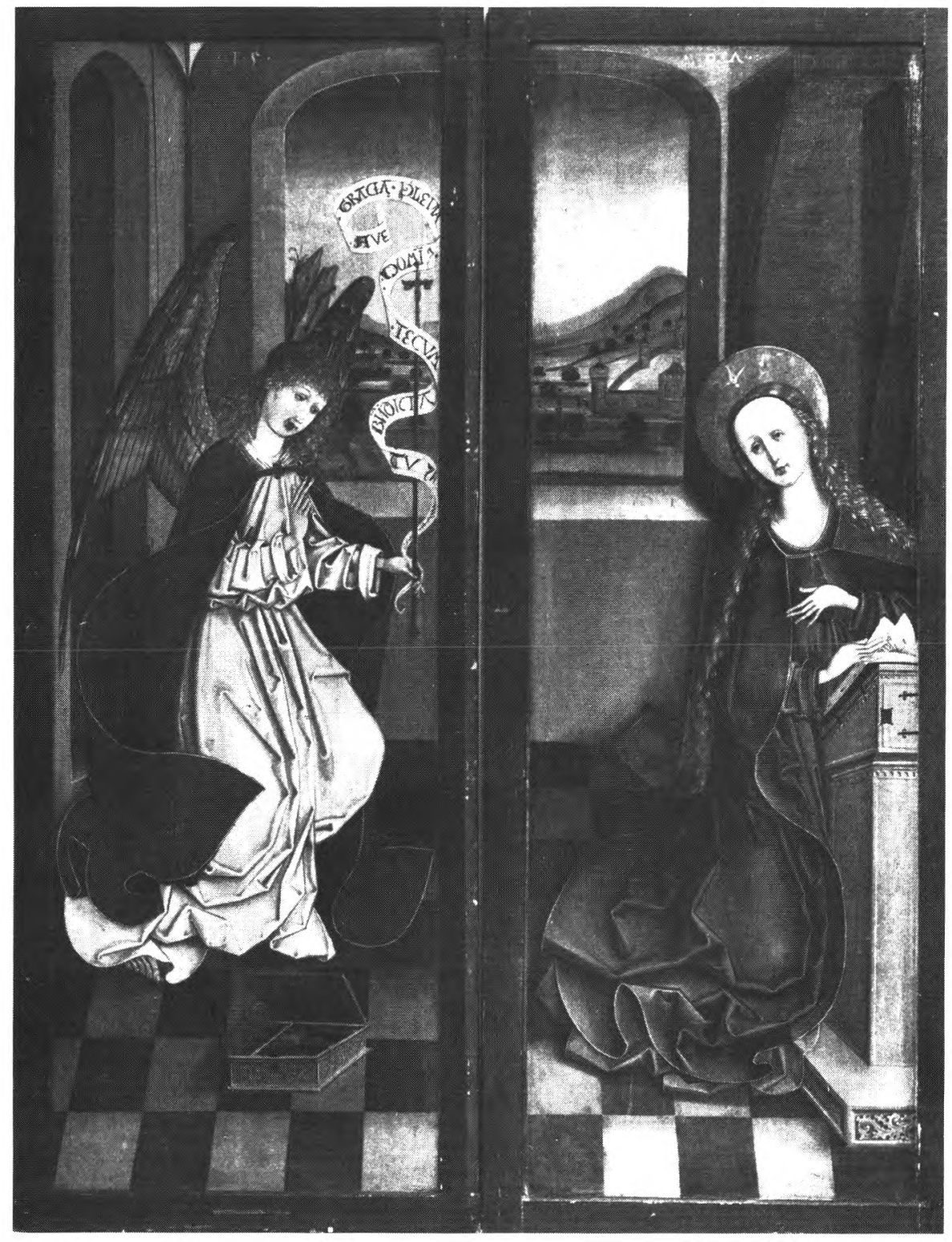

21. Rewersy skrzydeł pentaptyku z 1507 r., z kościoła św. Bartłomieja w Koninie Żagańskim, w Muzeum Narodowym we Wrockawiu. Fot. St. Stępniewski. 


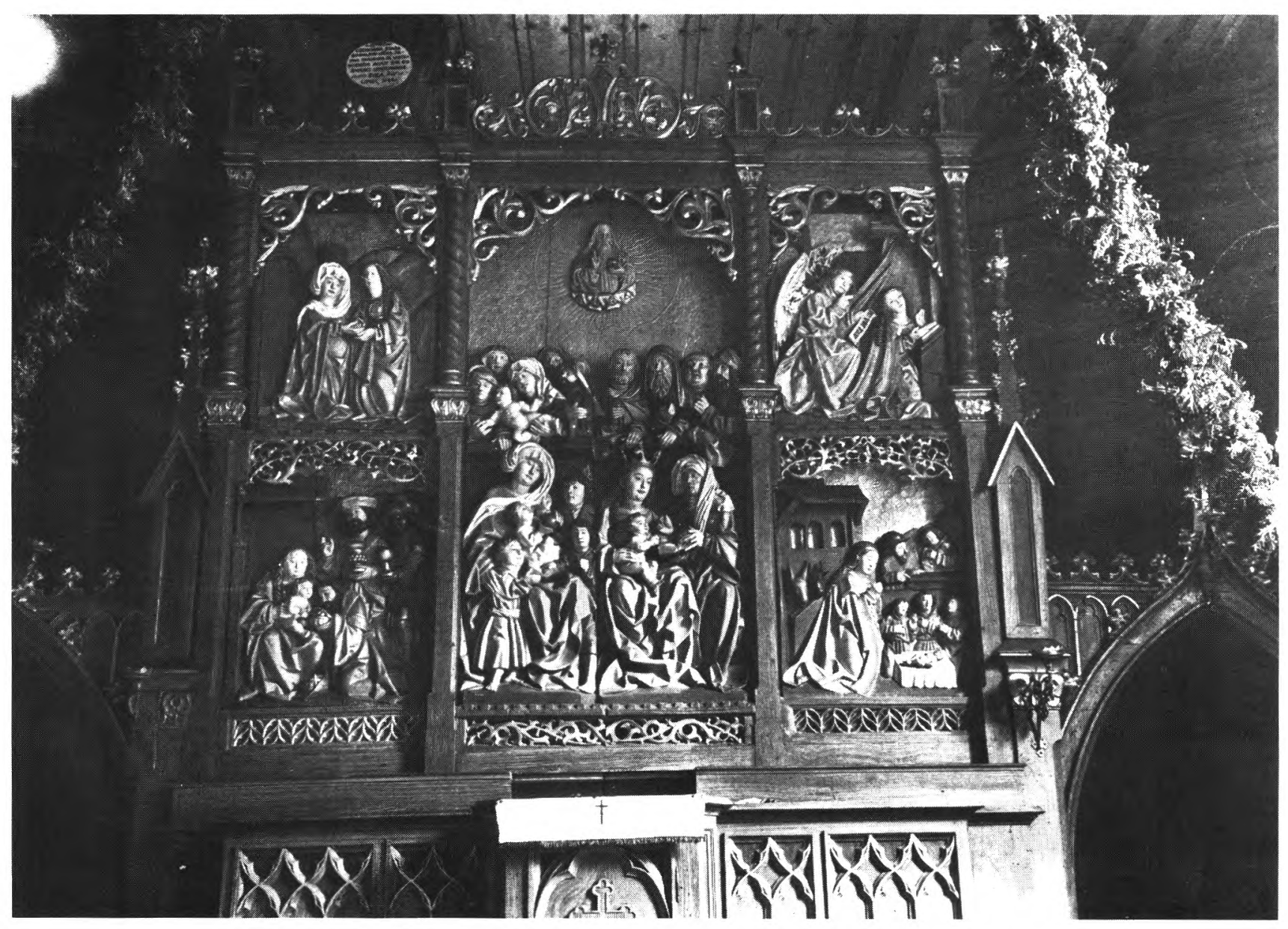

22. Kwatera tryptyku z pocz. XVI w. w kościele odpustowym Św. Anny w Oleśnie. Fot. Chrzanowski. 
nie jak pędy roślinne przetykane złotem, a wyrastające ze szczytu portyku (pędy te są tego samego koloru, co litera u swych początków w miejscu, w którym wyrastają z portyku, potem przechodzą w zieleń i rozbielony kobalt oraz barwę winną). Tak więc łączą się one z literą kolorystycznie naocznie podkreślając treść tekstu o różdżce z pnia Jessego.

Ten pęd wyrasta z portyku, który można by określić jako część prezbiterialną kościoła albo kaplicę, typ budowli, jaki prezentuje miniatura w Matych godzinkach księcia Jana de Berry autorstwa Jacquemarta de Hesdin (Paryż, Bibl. Nat., ms. lat. 18014, fol. 22r. sprzed 1402 r., a prawdopodobnie około 1390 r.) ${ }^{94}$ lub miniatura w kodeksie Jana z Jenstejnu (z lat 1396 - 1397, w Bibliotece Watykańskiej) ${ }^{95}$, w których zainicjowany jest kościelny charakter budowli. Jeżeli teraz zidentyfikujemy Marię jako tę, o której mówi tekst napisany w książce leżącej na pulpicie (Iz. 7,14), okaże się, że jest tu mowa o poczęciu i dziewictwie Marii. Jeżeli Ona stoi w kaplicy (kościele), to symbolizuje to, iż sama staje się kościołem dla Chrystusa w chwili poczęcia ${ }^{96}$.

W Antyfonarzu $n r 1$ w centrum kaplicy stoi okorowany pień drzewa (widać słoje drzewa), który jest pulpitem na książkę. Wyrasta on z podłogi, wykonanej z tego samego materiału, co pień, i położonej na dwóch zielonego koloru słupach. Zieleń u średniowiecznych teologów kojarzona była z wegetacją, z ogrodem rajskim i nadzieją na szczęście wiekuiste ${ }^{97}$. Tekst Iz. 11,1 mówi, że królewski ród Dawida wskutek kataklizmów dziejowych stanie się podobny do ściętego drzewa. Jednakże z pnia wyrośnie nowy pęd, wybitny potomek. Ojcowie Kościoła, oprócz znaczenia chrystologicznego, dopatrywali się w tym tekście sensu mariologicznego, przy czym aluzja fonetyczna virga - 'różdżka' virgo - 'dziewica' odgrywała tu pewną rolę ${ }^{98}$. Różdżka w średnich wiekach stała się symbolem czystości Marii ${ }^{99}$. Św. Ildefons z Toledo, mówiąc o wieczystym dziewictwie Najświętszej Marii Panny, interpretuje tekst Iz. 11,1 mariologicznie. Twierdzi on, że Maria wyjdzie ,jako różdżka z pnia Jessego [...] to jest $\mathrm{z}$ jego narodu zrodzona, która wydała ten kwiat, Chrystusa, duchowym tylko wlaniem bez skażenia człowieka"100.

W Antyfonarzu Zbigniewa Oleśnickiego Maria stoi po prawej stronie miniatury w otwartym portyku, który jest połączony łukiem żebrowanego sklepienia $\mathrm{z}$ wieżą o trzech otworach okiennych, namalowaną po przeciwległej

krok, wiążąc arkadę z samą sceną, z jej architekturą, jak to pokazuje miniatura jego autorstwa w Biblii Jana de Vandetar z 1371 r. Mistrz Boucicaut zajął się logicznym powiązaniem przestrzeni wewnątrz arkady z samą arkadą i definicją sceny wewnątrz arkady; por. B ir k m e y e r K. M., jw., s. $8-9$.

${ }^{94}$ Robb D.M., jw., s. 485 - 496 (fig. 21).

95 Pieńkowska H., jw., s. 53 (fig. 17).

${ }^{96}$ Por. Pa n of s k y E., Early Netherlandish Painting..., s. 132.

97 Rzepińska M., jw., s. 130.

98 Stary Testament, t. 2, Poznań 1975, s. 708 - 709 (komentarz do Iz. 11,1).

${ }^{99} \mathrm{H}$ all J., s. 1 (hasło: Aaron).

100 Ojcowie Kościoła tacińscy..., s. $170-171$. 
stronie miniatury. Ta kompozycja tworzy inicjał $A$, bez poprzecznej kreski ${ }^{101}$. Pędy wyrastające z żebrowanego sklepienia i dolnej części wieży (w tym pędzie znajduje się popiersie Izajasza) wskazują zapewne na Izajaszowe proroctwo (Iz. 7,14; 11,1), którego sens na tej miniaturze podkreślony jest jeszcze przez dodatkowe elementy symboliczne. W portyku za Marią rozpostarta jest tkanina, zawieszona na słupkach podpierających dach.

Maria Michnowska analizując symbolikę szaty zarzuconej na ramiona ukrzyżowanego Chrystusa w scenie będącej wykładem nauki o Trójcy Swiętej i Odkupieniu, poliptyku toruńskiego, pisze, że w chwili inkarnacji tunika człowieczeństwa Jezusa utworzona została z ciała Marii. Ona (Maria), jak twierdzi św. Bonawentura w Speculum humanae salvationis, jest tuniką człowieczeństwa, w którą odziała się Bożą Mądrość102.

Tunika ta kojarzy się także z opisem apokryficznym, według którego Maria wraz z innymi dziewicami wykonywała zasłonę do świątyni. Na obrazie Melchiora Broederlama (scena zwiastowania Marii z ołtarza z Champmol koło Dijon, obecnie Dijon, Musée des Beaux-Arts) Maria siedzi w portyku na ławie wyściełanej purpurową tkaniną, trzymając w rękach kłębek wełny o tym samym kolorze. E. Panofsky interpretując tę scenę, stwierdza, że purpura symbolizuje dziewictwo Marii, która jest zamknięta w wieży. Wieża na obrazie Broederlama jest wspomnieniem mitu o Danae, zamkniętej w „turris aënea”, aby uchronić ją od kontaktu z mężczyzną. Stąd wieża była symbolem niewinności (czystości), nie tylko w znaczeniu ogólnym (jak to jest na fresku w dolnym kościele w Asyżu), lecz także w odniesieniu do Zwiastowania w szczególności (jak na obrazie Guido da Siena z Princeton i jego pochodnych). Wieża, jako miejsce zwiastowania, pojawia się w malarstwie francuskim i włoskim XIV wieku. Panofsky, który zwrócił uwagę na te przykłady, odniósł ten niedostępny rodzaj architektury do czystości Marii ${ }^{103}$. Księga Pieśni nad Pieśniami $(4,4)$ opisuje oblubienicę: Szyja twoja jak wieża Dawidowa. W Zwiastowaniu Broederlama w Dijon w lekkiej gotyckiej szczytowej nadbudowie występują trzy okna, przez które przedziera się złote tło. Są one symbolem oświecającej łaski, a stąd nowego światła (lux nova) wiary chrześcijańskiej jako przeciwieństwa do ciemności i ślepoty judaizmu. Oznaczają one Trójcę Swiętą, która przybiera formę fizycznego istnienia w akcie Chrystusowej inkarnacji. Maria zaś może być tutaj uznana jako świątynia, sanktuarium Trójcy Świętej (Templum Trinitatis), co też (jako dalszą aluzję) symbolizuje lampa z trzema „zniczami”, zawieszona u sufitu nad Marią siedzącą w loggi ${ }^{104}$. Na miniaturze w Antyfonarzu Oleśnickiego wieża i trzy okna widoczne w jej ścianie mają, być

101 Miodońs k a B., Iluminacje..., il. 18.

$102 \mathrm{Mich}$ nows k a M., Ze studiów nad poliptykiem toruńskim, [w:] Teka Komisji Historii Sztuki, t. 2, Toruń 1961, s. 160-168.

103 Pa n of s k y E., Early Netherlandish Painting..., s. 132 (przypis 4).

104 Tamże, s. 132. 
może, podobny wydźwięk jako obecność Trójcy Świętej w dziele poczęcia, która w osobie Chrystusa przybiera ludzką postać w łonie Marii Dziewicy ${ }^{105}$.

Graduale gnieźnieńskie, wykonane dla klarysek w Gnieźnie, podobnie jak wymieniony Antyfonarz $n r 1 \mathrm{w}$ kościele Bożego Ciała, posiada miniaturę Zwiastowania Marii z inicjałem $A$ (d te levavi), który tworzy arkadę dla sceny rozgrywającej się w jej wnętrzu (tutaj też litera $A$ i scena wewnątrz niej nałożone są na prostokątne złote tło z ramą). Oprócz znanych elementów jak: portyk, kotara za Marią rozwieszona na kolumnach portyku, pulpit z otwartą książką i popiersie Izajasza z szarfą (prorok palcem prawej ręki wskazuje napis na szarfie: Isayas...), występuje tutaj Bóg Ojciec w połowie postaci, z książką w ręce, objawiający się w obłoku oraz bordiura z motywem dzikich ludzi i ptaka. Popiersie Boga Ojca wystąpiło już na Śląsku we wspomnianym kodeksie lubińskim z 1353 r., zawierającym legendę o św. Jadwidze ${ }^{106}$ (tutaj Bóg Ojciec trzyma Dzieciątko - „parvulus puer formatus”), na jednym z dwóch skrzydeł tryptyku malarza śląskiego (XIV w.) ${ }^{107}$, w Missale $\mathrm{nr} 1115$ (il. 17) ${ }^{108}$ i na płaskorzeźbionej kwaterze ołtarzowej ze Zgorzelca109. W sztuce włoskiej Boga Ojca, jak błogosławiąc zwraca się ku Marii, ukazuje jedna z mozaik Jacopo Torriti w apsydzie bazyliki S. Maria Maggiore w Rzymie (1290 r.), na której też od Boga Ojca w kierunku Marii po strumieniu światła zlatuje gołąbek. Ponieważ strumień światła wychodzi z ust Boga, jest on niejako Słowem Bożym, które staje się ciałem ${ }^{110}$.

Jeżeliby uznać portyk z kotarą, w którym Maria klęczy ze skrzyżowanymi na piersiach rękami przed otwartą książką, za świątynię, to ptak stojący na szczycie tej budowli (na kominie?) mógłby ilustrować modlitwę Marii. Barbara Miodońska bowiem, omawiając Iluminacje krakowskich rękopisów z 1. potowy w. XV w Archiwum Kapituty Metropolitalnej na Wawelu, mówi, że na kartach rękopisów wawelskich „szczególnie liczne są pięknie upierzone barwne ptaki o smukłych kształtach, długich skrzydłach i ogonach, drobnych główkach, ozdobionych często czubkiem, nie dające się bliżej określić pod względem ornitologicznym. Należą one do [...] grupy szybko i wysoko latających ptaków symbolizujących duchową stronę natury ludzkiej, wzlot duszy do Boga. Taką ich interpretację potwierdza fakt, że występują one z reguły tam, gdzie wprowadzenie momentu modlitwy, adoracji bóstwa jest jak najbardziej

105 O tym, że troistość symbolizowała Trójcę Swiętą świadczy między innymi legenda, która mówi, że św. Barbara wzbudziła gniew swojego ojca, poganina, ponieważ pouczyła jego robotpika, aby zaopatrzył nowy budynek w trzy okna, zamiast dwóch, by symbolizowały Trójcę Świętą; por. Pa n of k y E., The Friedsam Annunciation and the Problem of the Ghent Altarpiece, „The Art Bulletin" 17: 19534 s. 450 (przypis 30).

${ }^{106} \mathrm{~K}$ a rłow s k a-K a m zow a A., Malarstwo ślaskie $1250-1450 \ldots$, s. $23-24,110-111$; Dobrzeni ecki T., Prezentacja Marii ẃwiatyni..., s. 11 (przypis 52).

107 Dobrzeniecki T. Malarstwo tablicowe..., s. 183; Karłow ska-Ka mzowa, Malarstwo śląskie $1250-1450 \ldots$, s. $45-46$.

108 Podla ch a W1., Minjatury śląskie, Kraków 1935, s. 228 (tabl. LXXIV).

109 Braune H., Wiese E., jw., s. 36 (il. 182).

110 Schiller G., jw., s. 55 (il. 96). 
na miejscu. Tak więc spotykamy je na początku mszału, przy tekście introitu Ad te levavi animam meam, Deus meus, zilustrowanym postacią modlącego się Grzegorza Wielkiego (Mszat nr 7, fol. 1, fig. 62), przy przedstawieniu Boga na majestacie (Antyfonarz nr 47, fol. 305), obok Zwiastowania, gdzie mogą oznaczać zarówno modlitwę Marii, jak i duszę ludzką, uciekającą się pod opiekę Marii (Pontyfikat Oleśnickiego, fol. 171, Mszat nr 7, fol. 236)"111. Dziki człowiek i błazen z piszczałką i koroną na głowie, podkreślają tylko dziewicze poczęcie, tryumf czystości, których są oni antytezą ${ }^{112}$. W miniaturze jest zastanawiające, że, podobnie jak to było w Antyfonarzu nr 1 z kościoła Bożego Ciała w Krakowie, inicjał $A$ powiązany jest ze szczytem portyku i jest on gałązką, w której lewej odnodze, usytuowanej w lewym dolnym rogu miniatury (już poza ramą ze złotym tłem), namalowane jest popiersie Izajasza oraz, że z tej gałązki, po lewej i prawej stronie szczytu (komina?), na którym stoi ptak, wyrastają także dwie odnogi zwinięte spiralnie ku stojącemu ptakowi. Pulpit natomiast, stojący przed Marią, utworzony jest z dwóch sześcianów, na których bokach, podobnie jak to jest na miniaturze Antyfonarza nr 1, widać słoje drewna. Może jest to ilustracja proroctwa Iz. 11,1, bo na stronicach otwartej książki jest wypisany wers 14 rozdziału 7 Izajasza proroka.

Po bokach sceny zwiastowania, na czaszy tzw. kielicha Dąbrówki z Trzemeszna (il. 18) ukazane są dwie sceny ze Starego Testamentu: Mojżesz przy krzaku ognistym i Aaron z kwitnącą różdżką, które odnoszą się do wątku Wcielenia jako najważniejszego w tej części programu ikonograficznego kielicha (obok zwiastowania Marii na czaszy występuje scena Narodzenia Pana Jezusa). Na brzegu czaszy wyryta jest inskrypcja: Matre Deo digna sunt haec pro Virgine signa ${ }^{113}$.

Aaron i Mojżesz w tym kontekście, przez swoje wybranie do spełnienia określonych zadań naznaczonych im przez Boga, podkreślają rolę Marii w dziele inkarnacji. Różdżka, przed którą stoi Aaron, zakwitła jako znak jego wybrania na kapłana (Lb. 17,16-26). W mszale z 1160 roku, który został napisany przez prezbitera Heinricha z klasztoru św. Michała w Hildesheim (Stammheim, Bibl. des Grafen Fürstenberg), na miniaturze zwiastowania Marii ukazane są nowotestamentowe wydarzenia oraz ich typologiczne przeciwstawienia, aby ukazać ich wzajemną wspólzależność w historii zbawienia i przedstawić Marię depczącą węża jako Dom Mądrości. Aaron, który trzyma w ręku rózgę nie jest tu tylko antytezą Kościoła Chrystusowego, ale ów cud z różdżką jest przesłanką wybrania Marii i jej dziewiczego macierzyństwa ${ }^{114}$. Przykład dojrzewania owocu na lasce Aarona, bez uprzedniej troski o jego

111 Miodońs k a B., Iluminacje, s. 76.

112 Tamże, s. 86 - 88; taż, Motywy Mistrza Kart do Gry i jego kopisty w krakowskich rekopisach iluminowanych okoto połowy XV wieku, „Biuletyn Historii Sztuki” 39 : 1977 z. 1 il. 6, 14.

${ }^{113}$ S k ubiszew ski P., Programy obrazowe..., s. 15.

114 Schiller G., jw., s. 51 (il. 86). 
wzrost, wraz ze słownym podobieństwem łacińskiego słowa virgo $\mathrm{z}$ virga, co już było wspomniane, doprowadziły w średnich wiekach do uznania migdału jako symbolu dziewiczej czystości115.

Krzak, wewnątrz którego widać popiersie Boga, płonął, kiedy Bóg wybierał Mojżesza, aby wyprowadził Izraelitów z niewoli (Wj. 3,1-22). Gorejący krzak, który jednak nie spłonął, symbolizuje Marię, która porodziła Chrystusa, pozostając dziewicą w takim samym stopniu, jak nią była przed, w czasie i po narodzeniu Syna Bożego (ante partum, in partu et post partum $)^{116}$. W takim znaczeniu użył tego typu starotestamentalnego autor kielicha w Werben (kościół Św. Jana, około połowy XIII w.), który na stopie kielicha scenę Mojżesza przed krzakiem gorejącym wraz z przedstawieniem runa Gedeona pokazał po bokach zwiastowania Marii ${ }^{117}$.

Wiele spośród przedstawień zwiastowania Marii w komnacie ukazuje anioła, który wszedł do wnętrza przez zamknięte drzwi. Są to: Conradus de Malberstadt, Concordantiae Bibliorum, 1472 r., Mateusza z Oleśnicy (Wrocław, Bibl. Uniw. IF 88) ${ }^{118}$, kwatera ołtarza z lat między 1473 a 1478 r., z kaplicy bractwa kapłańskiego w kościele Mariackim w Gdańsku ${ }^{119}$; kwatera ołtarza Wita Stwosza, z lat 1477 - 1489, w kościele Mariackim w Krakowie ${ }^{120}$; kwatera tryptyku z 1491 r. w kościele par. Wniebowzięcia Najświętszej Marii Panny w Książnicach Wielkich (il. 19) ${ }^{121}$; kwatera oltarza z ok. 1500 r. z Lusiny (il. 20) ${ }^{122}$; kwatera poliptyku z ok. 1500 r. w kolegiacie p. w. Wniebowzięcia NMP w Kaliszu ${ }^{123}$; rewersy skrzydeł pentaptyku z 1507 r., z kościoła p. w. św. Bartłomieja w Koninie Żagańskim (il. 21) ${ }^{124}$; rewersy skrzydeł ołtarzowych z pocz. XVI w. w kościele katolickim w Żaganiu ${ }^{125}$ i kwatera tryptyku z pocz. XVI w. w kościele odpustowym św. Anny w Oleśnie (il. 22) ${ }^{126}$.

Zamknięte drzwi komnaty (thalamus Virginis) prawdopodobnie występują na obrazie zwiastowania Marii z lat 1434 - 1435 Rogera van der Weydena,

115 Hall J., jw., s. 1.

116 Tamże, s. 214; odnośnie dziewictwa Najśw. Marii Panny patrz: Florkowski E., jw., s. 59 nn.; D rozd J., Maryja w roku kościelnym, Kraków 1983, s. 53 - 54.

117 S ku biszew ski P., Programy obrazowe..., s. 94 (katalog ikonograficzny nr 69-70).

118 Kloss E., jw., s. 190 (il. 235).

119 Dobrzeniecki T., Malarstwo tablicowe..., s. 135-140(il. 41 C1A); Labuda A., Malarstwo tablicowe..., s. 53 - 58 (il. 2).

${ }_{120}$ Det t l off Sz., Wit Stosz, t. 1, Wroclaw 1961, s. 32, $41-42$.

$121 \mathrm{G}$ a d o m s k i J., Gotyckie malarstwo tablicowe Matopolski 1460 - 1500, Warszawa 1988, s. $158-159$ (il. 145 )

122 S. Dettloff, Wit Stosz, t. 1, Wrocław 1961, s. $44-47$; Olszews ki A., Die gotische Sculptur der Jagiellonen-Zeit, [w:] Polen in Zeitalter der Jagiellonen 1386 - 1572, Schallaburg 1986, s. $288-289$, il. na s. 288 .

123 M roczk o T., Poliptyk kaliski a rzeźby ze Stawiszyna. Próba rekonstrukcji, „Biuletyn Historii Sztuki” 24 : 1962 z. 1 s. 58 - 72; Katalog zabytków sztuki w Polsce, t. 1 z. 6 s. 6 (fig. 79).

${ }^{124}$ Braune H., Wiese E., jw., s. 68-69 (il. 138); Zi o mecka A., Ślaskie malarstwo gotyckie. Zbiory Muzeum Narodowego we Wroctawiu, Wrocław 1986, s. 60-62 (il. 15c - d).

125 Braune H., Wiese E., jw., s. 92 (il. 194).

126 Katalog zabytków sztuki w Polsce, t. 7 z. 10 (fig. 61). 
w Muzeum Luwru w Paryżu ${ }^{127}$, a także w innym dziele tego malarza, na skrzydle ołtarza z lat około 1458 - 1459 (nie później niż 1462 r.), z kościoła Św. Kolumbana w Kolonii (Monachium, Alte Pinakothek) ${ }^{128}$. Ukazuje je opublikowany przez M. Sonkes rysunek berliński, który w swojej kompozycji ikonograficznej, za pośrednictwem Mistrza Górnoreńskiego ${ }^{129}$ wskazuje na Mistrza z Flémalle. Są one przedstawione na kwaterze skrzydła ołtarza z około 1445 r. Konrada Witza, pochodzącego przypuszczalnie z kościoła klasztornego w Olsberg (Norymberga, Germanisches National-Museum) ${ }^{130}$.

Znaczenie zamkniętych drzwi komnaty tłumaczą Ojcowie Kościoła, mówiąc o dziewictwie Marii i komentując Księgę Ezechiela 44,2 n. Tekst św. Jana Damasceńskiego z homilii na Wniebowzięcie NMP koresponduje w szczególny sposób ze zwiastowaniem na poliptyku kaliskim z 1500 r., na którym anioł trzyma w prawej ręce list zapieczętowany, wcześniej wchodząc do wnętrza komnaty przez zamknięte drzwi, namalowane na ścianie znajdującej się za jego plecami. Przez biforialne okno z kolumną widać w pejzażu mur otaczający miasto, w którym wyeksponowana jest brama, podobnie jak to jest w zwiastowaniu na rewersach skrzydeł pentaptyku z kościoła Św. Bartłomieja w Koninie Żagańskim. Św. Jan Damasceński wzywa „,boskiego Ezechiela”, aby wystąpił i wskazał „zamkniętą bramę, dostępną Panu, choć nie otwartą, jak to w proroczy sposób przepowiedział; niech powie, iż spełniły się jego słowa. Wskaże na pewno, żeś Ty jest oną bramą, przez którą Bóg wszechrzeczy przeszedl i wziął ciało, choć nie otworzył pieczęci dziewictwa. Pieczęć bowiem pozostaje na zawsze" 131 . Św. Ildefons z Toledo w kazaniu $O$ wieczystym dziewictwie Najświętszej Maryi Panny, oprócz komentarza do tekstu Ez. 44,1, że Maria jest bramą zamkniętą, „,bo zawsze jest Dziewicą”, dodaje, że „ta Dziewica w psalmie jest komnatą Boga, ponieważ z Jej łona wyszedł wcielony Bóg jako oblubieniec, pozostawiwszy w Niej ozdobę wieczystego dziewictwa" (Ps. 19,6) ${ }^{132}$.

W średniowieczu św. Bernard i inni opisywali pokój, w którym dokonało się zwiastowanie jako całkowicie pozbawiony innej ludzkiej istoty poza Marią. Sw. Bernard pyta: Dokad wszedt (Gabriel)?, i odpowiada: Sadzę, że do skrytości skromnej izdebki, gdzie Maria, może drzwi za sobq zamknqwszy modlita się do swego Ojca w ukryciu (...) I nie trudno byto Aniołowi dostać się drzwiami zamkniętymi do ukrycia Dziewicy, bo przecież on dzięki przenikliwości swej istoty to ma w naturze, że dokądkolwiek wtasny go niesie pęd, tam nawet żelazne zapory wejścia nie wzbroniq ${ }^{133}$. W kazaniu w oktawie Wniebowzięcia

$127 \mathrm{P}$ a n of s k y E., Early Netherlandish Painting..., s. 252 - 255 (il. 310).

128 Tamże, s. $286-287$ (il. 254).

129 So n k es M., Dessins du XVe siècle: Groupe van der Weyden. Les primitifs flamands, Bruxelles 1969.

${ }_{130} \mathrm{Schille}$ r G., jw., s. 213 (il. 112).

131 Ojcowie Kościoła greccy i syryjscy..., s. 238.

132 Ojcov'ie Kościota tacińscy..., s. 171, 178.

133 Św. B rnard, Kazania o Najśw. Marji Pannie, tł. ks. Ildefons B o bicz, Kielce 1924, s. $31-32$; Freeman M., jw., s. 135. 
N.M.P. mówi: Ja to bowiem oznaczaty różdżka kaptańska kwitnaca, lubo nie mająca korzenia (Num, 17,8); runo Gedeona, okrywające się rosq na środku suchego bojowiska (Sęd. 6,37-38); brama wschodnia, która nigdy nikomu otwarta nie byta, $w$ widzeniu Ezechiela $(E z .44,1,2)^{134}$. Podobnie, cytując Ezechiela 44,2n., Tomasz a Kempis w swoich Medytacjach nad Wcieleniem Chrystusa pisze, że „Maria jest zamkniętą bramą, która w poczęciu i porodzeniu pozostała zawsze nietkniętą dziewicą"135.

Podsumowując, można stwierdzić, iż zastosowany w pracy podział na określone motywy ikonograficzne stwarza konieczność ograniczenia się do pewnego rodzaju symbolu, który występuje w danej scenie zwiastowania Marii, często posiadającej zespół elementów tworzących całość ikonograficzną przedstawienia. W większości jednak przypadków omawiany motyw jest głównym elementem ikonograficznym opisującym wydarzenie zwiastowania Marii. Ich rodzaj i częstotliwość występowania dają możliwość rozeznania popularności danego motywu a związek ze sztuką europejską wskazuje na przejmowanie określonych motywów przez różne ośrodki twórcze w Polsce. Oczywiście na świadome przejmowanie motywów wskazują antyfonarz ufundowany przez bpa Oleśnickiego i antyfonarz z kościoła Bożego Ciała w Krakowie, w których następuje powiązanie tekstu antyfony z miniaturą. Antyfonarze te zawierają im tylko właściwą interpretację obrazową tekstu antyfony.

\section{DIE DARSTELLUNGEN DER VERKÜNDIGUNG MARIÄ IN DER POLNISCHEN KUNST DES MITTELALTERS}

\section{Zusammenfassung}

Diesem Artikel wurde die Aufgabe gestellt, die in den polnischen Werken auftretenden ikonografischen Motive darzustellen und zu interpretieren, sowie bestehende Zusammenhänge zwischen ihnen und den von ihnen früheren europeischen Szenen der Verkündigung Mariä aufzuzälen.

Die Konzeption der Einverleibung àls der Vermählung Mariä mit Bräutigam, mit dem Bett innerhalb der Wohnung und dem Heiligen Geist, der in Gestalt einer Taube vom Medaillon mit Vater Gott auf Maria hinabfält, ist auf der heute nicht mehr bestehenden Wandmalerei in den Kreuzungen Dominikaner in Krakau dargestellt. Sie geht auf die italienische Malerei der Trezentzeit zurück, aber auch auf die flämische und deutsche. Theologisch gesehen hat sie ihre Ursprünge in Geständnissen Augustins und wurde weiterhin durch Rupert von Deutz und Honorè von Autun weiterentwickelt. Besonders interessantes Zeichen, das seinen Widerhall bei der Ablegung der Klostergelübde hat, ist die Krone auf die Schläfen Mariä, die auf dem Gemälde in Zagórze durch

134 Sw. Bernard, jw., s. 116.

${ }^{135}$ Freeman M., jw., s. 135. 
zwei Engeln aufgesetzt wird und die Krönungsfeierlichkeit, die mit der Bewegung des nackten Kindes in der Richtung von der Büste Vater Gott auf Maria synchronisiert ist. Auf der Glasmalerei in Chełm gibt es außer Heiligen Geist und Mariä Krone auch die in Leuchter stehende und brenende Kerze.

Die Gegenüberstellung Mariä-Eva (Paradisi porta) ist auf der Kalisz-Patene dargestellt, wo Märia und ein Engel am Paradiseingang stehen. Zu diesem Gedanken knüpfen zahlreiche Darstellungen der aufgemachten Tür zu Mariä Kammer an. Die Szenen mit neben Mariä wachsenden Paradisbaum unterstreichen Mariä Gehorsam und Evas Ungehorsam. Das Motiv sub lege sub gratia enthält die Wandmalerei in Czchów, wo ein aus dem Boden wachsender und Sprößlinge treibender Paradisbaum einen Stuzbein für den Pult bildet, auf dem Mariä Psalter liegt.

Im Lubiąż-Antiphonar (IF 401) wird die Szene durch folgendes beschrieben: Christus in der Paradisbaumkrone, Habakuk, Dawid und Gedeon und an der Schale des sog. Dabrówkas Kelches Aaron und Mose. Die geschlossene Tür Mariä Kammer auf vielen Darstellungen und die hinter dem Fenster sichtbare Stadt, von Mauern umlegen mit einem geschlossenen Tor unterstreichen die Prophezeihung Hesekiels 44,2. Von besonderer Bedeutung sind die Miniature im Kathedral-Antiphonar von Oleśnicki (KP 47) und im Antiphonar nr 1, in der Leib-Christi-Kirche in Krakau und auch in Gradual von Klarisken (Die Stiftung von Katarzyna aus Zagajewo und Kan. Mikołaj Goszczyński) in Gniezno, die den Text Jesajas 11,1 wiederspiegeln, enthalten in Antiphonen und Jes 7,14, eingeschrieben im auf dem Pult gelegenen Buch. Bei Oleśnicki ist eine Turm mit drei Fenstern (Jungfernschaft und Dreifalltigkeit) in Pflanzenverflechtung gezeigt. Im Antiphonar nr 1 eine Holzkapelle auf Baumstämmen und in der Ruteverflechtung, "was auf die französische und böhmische Malerei zurückgeht. Die Miniature weisen auf eine große Selbständigkeit in der Interpretation der angenommenen Symbolik hin. 